Volume 3

Issue 1 The Syriac Galen Palimpsest

Article 6

5-9-2019

\title{
The Syriac Galen Palimpsest: A Tale of Two Texts
}

Naima Afif

The University of Manchester, naima.afif@manchester.ac.uk

Siam Bhayro

University of Exeter, s.bhayro@exeter.ac.uk

Grigory Kessel

The University of Manchester \& Austrian Academy of Sciences, Grigory.Kessel@oeaw.ac.at

Peter E. Poormann

The University of Manchester, peter.pormann@manchester.ac.uk

William I. Sellers

The University of Manchester, william.sellers@manchester.ac.uk

See next page for additional authors

This paper is posted at ScholarlyCommons. https://repository.upenn.edu/mss_sims/vol3/iss1/6

For more information, please contact repository@pobox.upenn.edu. 


\title{
The Syriac Galen Palimpsest: A Tale of Two Texts
}

\begin{abstract}
This article presents the Syriac Galen Palimpsest's double history, of both the original manuscript and its subsequent reuse. The original medical manuscript contained Galen's Book of Simple Drugs in Syriac translation, was probably produced in northern Mesopotamia or western Syria, and dates to the first half of the ninth century. After only two centuries, it was erased and reused to produce a liturgical text called Octōèchos, probably at the monastery of Saint Elias on the Black Mountain. This palimpsest was later transferred to Saint Catherine's monastery in the Sinai, where it remained for several centuries before being offered for sale in Leipzig in 1922 (perhaps due to the activities of Friedrich Grote). We pay close attention to the context, contents, codicology and palaeography of both the original manuscript and the palimpsest. We also contextualise both texts within the wider story of their transmission. Through the "skeleton" table we present the latest results of our almost complete identification of the undertext. We reconstruct the structure of the original codex through a collation diagram. We draw palaeographical parallels with a dated colophon of the well-known Sahdona-manuscript. This permits us to narrow done the time and place of production of the original manuscript.
\end{abstract}

\section{Keywords}

Syriac Galen Palimpsest, Codicology, Palaeography, Octốēchos, Galen, On Simple Drugs

\section{Authors}

Naima Afif, Siam Bhayro, Grigory Kessel, Peter E. Poormann, William I. Sellers, and Natalia Smelova 


\title{
MANUSCRIPT STUDIES
}

A Journal of the Schoenberg Institute for Manuscript Studies

\author{
VOLUME 3, NUMBER 1
}

(Spring 2018)

\begin{abstract}
Manuscript Studies (ISSN 2381-5329) is published semiannually by the University of Pennsylvania Press
\end{abstract}

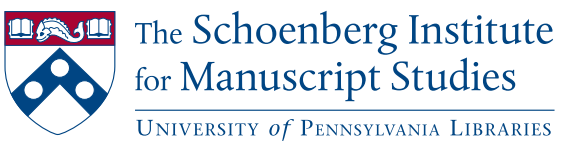




\section{MANUSCRIPT STUDIES}

A Journal of the Schoenberg Institute for Manuscript Studies

VOL UME 3, N UMBER 1

Special Issue:

The Syriac Galen Palimpsest

Editors: William Noel and Ralph M. Rosen

\section{Articles}

The Syriac Galen Palimpsest Project: An Introduction

William Noel and Ralph M. Rosen

Pulling It All Together: Managing the Syriac Galen

Palimpsest Project

Michael B. Toth

The Codicology and Conservation of the Syriac

Galen Palimpsest

Abigail B. Quandt and Renée C. WolcotT

Spectral Imaging Methods Applied to the Syriac

Galen Palimpsest

Roger L. Easton, Jr., Keith T. Knox, William A. Christens-Barry, AND Ken Boydston

The Galen Palimpsest and the Modest Ambitions of the

Digital Data Set

Doug EMERY

The Syriac Galen Palimpsest: A Tale of Two Texts

Naima Afif, Siam Bhayro, Grigory Kessel, Peter E. Pormann,

William I. Sellers, and Natalia Smelova 
iv | Journal for Manuscript Studies

Analyzing Images, Editing Texts: The Manchester Project

Naima Afif, Siam Bhayro, Peter E. Pormann, William I. Sellers,

and Natalia Smelova

The Textual Interest of the Syriac Versions of Galen's Simples

Irene Calà, Jimmy Daccache, and Robert Hawley 186

\section{Annotations}

Of Scribes and Scripts: Citizen Science and the Cairo Geniza

Laura Newman Eckstein

Preserving Endangered Archives in Jerba, Tunisia:

The al-Bāsī Family Library Pilot Project

Ali Boujdidi And Paul M. Love

The Intricacies of Capturing the Holdings of a Mosque

Library in Yemen: The Library of the Shrine of Imām alHādī, Șa da

Sabine Schmidtke

Compilation, Collation and Correction in the Time of Encyclopedism: The Case of UPenn LJS 55

Nathalie Lacarrière

Mapping Manuscript Migrations: Digging into Data for the History and Provenance of Medieval and Renaissance

Manuscripts

Toby Burrows, Eero Hyvönen, Lynn Ransom, and Hanno Wijsman

\section{Reviews}

Ahmad 'Abd al-Bāsit. Catalogue of the Private Collections of

Manuscripts in the Egyptian National Library

ELIAS G. SABA 
Manuscript Studies, Vol. 3 [2019], Iss. 1, Art. 6

Contents | v

David T. Gura. A Descriptive Catalogue of the Medieval and Renaissance Manuscripts of the University of Notre Dame and Saint Mary's College

LISA FAgin Davis 256

Christopher De Hamel. Meetings with Remarkable Manuscripts

Daniel Traister 260 
Afif et al.: The Syriac Galen Palimpsest: A Tale of Two Texts 


\title{
The Syriac Galen Palimpsest
}

A Tale of Two Texts

\author{
Naima Afir \\ The University of Manchester \\ SiAM BHAYRo \\ University of Exeter \\ GRIGORY KesSEL \\ The University of Manchester \\ Austrian Academy of Sciences \\ Peter E. Pormann \\ The University of Manchester \\ William I. Sellers \\ The University of Manchester \\ Natalia Smelova \\ The University of Manchester
}

NY PALIMPSEST IS JANUS-LIKE: it presents two faces. First we have
the original manuscript, which is later erased and recycled to pro-
vide new writing material. Second, we have the later manuscript as 
number of different original manuscripts used to produce a new one, as is the case in the famous Archimedes Palimpsest. ${ }^{1}$ The Syriac Galen Palimpsest (SGP), owned by the same person as the Archimedes Palimpsest, is a true Janus: only one manuscript, containing Galen's On Simple Drugs in Syriac, was used to make the new manuscript, which contains a liturgical text called Octóéchos (Eight modes).

In this article, we describe for the first time both faces of our Janus: the original manuscript and the new one. We shall begin with a detailed discussion of the manuscript's double history and suggest where it was originally produced and then reused; we shall also briefly touch on its modern provenance. Then we shall turn first to the content of the overtext - that is, the newer manuscript, written on the recycled folios, and then to the undertext. The latter involved some Sherlockian deductions, and we explain some of our methodologies in another article in this volume.

We want to warn the reader at this stage as well, for even for us, who have spent the best of part of the last five years researching the SGP, the shift from original to new manuscript is sometimes difficult. For instance, the folios of the original manuscript are bifolia in the new one. Both the original and the new manuscript have quires, folios, and pages. We have made every effort, therefore, to describe both manuscripts in their own right. And yet, our Janus not only has two faces but also is one whole, and that should always be borne in mind. Let us therefore begin with the double history of its production.

\section{History of the Manuscript, Reconstitution of the Palimpsest}

Any palimpsest by definition is produced twice and therefore has a double history, contrary to any standard book and manuscript. While preparing a manuscript for reuse, one erases not only the text it contains but also any

1 R. Netz and W. Noel, The Archimedes Codex: Revealing the Secrets of the World's Greatest Palimpsest (London: Weidenfeld \& Nicolson, 2007); R. Netz, W. Noel, N. Wilson, and N. Tchernetska, The Archimedes Palimpsest, 2 vols. (Cambridge: Cambridge University Press, 2011). 
112 | Journal For Manuscript Studies

historical information it offers, usually in the form of a colophon in which a scribe informs the readers how the manuscript was produced. ${ }^{2}$ As a rule, palimpsest colophons do not get preserved, although there are some very rare exceptions. ${ }^{3}$ In this respect, the SGP has been especially unfortunate because, in addition to the loss of the colophon of the original medical manuscript, the colophon of the liturgical manuscript-unusually for a Syriac manuscript - may have never been written. Any study of the SGP's history, therefore, can rely only on the available evidence, and our reconstruction may change as new evidence comes to light.

As shown elsewhere in this article, the paleographical characteristics of the original medical manuscript permit a reasonably precise dating, limiting it to the first half of the ninth century. Its provenance is less easy to pinpoint with precision. Nevertheless, among the known centers of Syriac manuscript production, the region of northern Mesopotamia and western Syria is the most likely possibility. The documented places of manuscript production in the period in question include Edessa, Harran, and Kallinikos. ${ }^{4}$

The SGP was produced during a time of dramatic change in Syriac scholarship in general. Syriac was a vibrant medium for scholarly discourse as late as the eighth century, but the gradual Arabization (particularly through the reforms of 'Abd al-Malik, r. 685-705) and refinement of Arabic scholarship appears to have somewhat overtaken Syriac. Scholars and monks from the Christian Syriac tradition adopted Arabic as their primary language of communication and learning. This accounts for the disappearance of many dozens and probably hundreds of Syriac scholarly texts and manuscripts much better than the assumption that there was a sudden loss of interest in scientific and secular texts. ${ }^{5}$ Upon examination, it is clear that manuscripts were recycled because either they were superseded by better versions (for example,

2 For ninth-century Syriac codicology, see S. P. Brock, "Syriac Manuscripts of the 9th-10th Centuries from a Codicological Perspective," Semitica et Classica 8 (2015): 157-64.

3 See, for example, W. H. P. Hatch, An Album of Dated Syriac Manuscripts, Monumenta Paleographica Vetera 2 (Boston: American Academy of Arts and Sciences, 1946), plate 2, p. [53].

4 Brock, "Syriac Manuscripts of the 9th-10th Centuries," 157-58.

5 S. P. Brock, "Changing Fashions in Syriac Translation Technique: The Background to Syriac Translations Under the Abbasids," Journal of the Canadian Society for Syriac Studies 4 (2004): 3-14 at 10-11. 
the Old Syriac Gospels that were replaced by the Peshitta) or their texts were no longer used-the latter is particularly true for medical texts. ${ }^{6}$ It should not come as a surprise, therefore, that the original medical manuscript of the SGP was reused only two centuries after its production. This very much reflects the changes that took place during that period; indeed, it is likely that many other manuscripts experienced the same fate.

Although we cannot rule out other possibilities, the medical manuscript appears to have been reused to make a liturgical book in the Rum Orthodox monastery known as that of the Prophet Elias (or St. Panteleimon), which is located on the Black Mountain to the northwest of Antioch and was renowned for its multilingual monastic community. ${ }^{7}$ The SGP's connection to the monastery of St. Elias is borne out by the close affinity of its bookhand to that of British Library (BL) Add. MS 14489, which was copied by John of Duqsa in the same monastery in the year 1045 CE. ${ }^{8}$ Curiously, another Syriac Rum Orthodox scribe, John son of Joseph, is known to have produced at least five manuscripts, four in St. Elias's monastery and one in the monastery of Mar Georgios in Daphne. ${ }^{9}$ This shows that there were other places of manuscript production and that scribes could be active in more than one monastery. It also suggests the superiority of St. Elias on the Black Mountain.

6 A. B. Schmidt, "Syriac Palimpsests in the British Library," in Palimpsestes et éditions de textes: les textes littéraires. Actes du colloque tenu à Louvain-la-Neuve (septembre 2003), ed. V. Somers (Leuven: Peeters, 2009), 161-86.

7 What is known as the Black Mountain in Greek, Syriac, Armenian, and some other Christian traditions of this area is a certain part (or parts) of the Amanus mountain range (Turkish Nur Dağlari) running along the Gulf of Alexandretta mostly in the Hatay province in southern Turkey, from Antioch to the south as far as Maraş to the north. See J. J. S. Weitenberg, "The Armenian Monasteries in the Black Mountain," in East and West in the Medieval Eastern Mediterranean, I Antioch from the Byzantine Reconquest Until the End of the Crusader Principality: Acta of the Congress Held at Hernen Castle in May 2003, ed. K. Ciggaar and M. Metcalf, Orientalia Lovaniensia Analecta 147 (Leuven: Peeters, 2006), 79-93.

8 An illustration appears in Hatch, An Album of Dated Syriac Manuscripts, plate clxxxiv, p. [235].

9 S. P. Brock, "Syriac Manuscripts Copied on the Black Mountain, near Antioch," in Lingua restituta orientalis: Festgabe für Julius Assfalg, ed. R. Schulz and M. Görg, Ägypten und Altes Testament 20 (Wiesbaden: Harrassowitz, 1990), 59-67 at 64-65. 


\section{4 | Journal For Manuscript Studies}

There is one further point that could connect the SGP to the Black Mountain. The Syriac liturgical book Paraklettiké, which is found on the upper-text of the SGP, is a translation of a Greek text. This translation was not an isolated undertaking but was part of the wider Constantinopolitanization or Byzantinization movement that aimed to conform the liturgical rite of the Antiochene patriarchate to the Byzantine. The details of this process are not well studied, but scholars seem to agree that it was especially dynamic in the aftermath of the Byzantine reconquest of the area, approximately in the last decades of the tenth century. ${ }^{10}$ The monastery of St. Elias was probably central to this process, not only in terms of translation activity but also with respect to the dissemination of new books. ${ }^{11}$ Given the early date of the SGP, it can be regarded as one of the first copies of the newly translated liturgical book.

As stated earlier, the SGP does not have a colophon. It also lacks reader's notes, although there are clear traces of liturgical use, such as wax stains. The very first folio of the manuscript, today preserved as Rome, Vatican Library, Vat. sir. 647, fol. 38, contains an Arabic note, probably written in the twelfth or thirteenth century, that states that the manuscript was donated to the monastery of St. Catherine on Mount Sinai. This accords with our knowledge that a group of Syriac manuscripts, dating from the tenth to the thirteenth century and produced in the Black Mountain, was transferred to Sinai and is still housed there; examples include Sinait. Syr. 20, $21,{ }^{12} 71,{ }^{13} 81$, and 111, and NF Syr. M15N)..$^{14}$ These manuscripts provide clear evidence for a connection between the two monastic centers.

10 J. Nasrallah, "La liturgie des patriarcats melchites de 969 à 1300," Oriens Christianus 71 (1987): 156-81 at 156-59. For a similar Byzantinization of the Jerusalem rite, see D. Galadza, Liturgy and Byzantinization in Jerusalem (Oxford: Oxford University Press, 2018).

11 Brock, "Syriac Manuscripts Copied on the Black Mountain," 66-67. Brock's conclusions can now be refined in light of more recent discoveries.

12 The colophon of the manuscript can be found today as Mingana syr. 658 (Brock, "Syriac Manuscripts Copied on the Black Mountain," 60-61; P. Géhin, "Manuscrits sinaïtiques dispersés III: les fragments syriaques de Londres et de Birmingham,” Oriens Christianus 94 [2010]: $14-57$ at 48-49).

13 The colophon of the manuscript can be found today as BL Or. 8607 (Brock, "Syriac Manuscripts Copied on the Black Mountain," 62; Géhin, "Manuscrits sinaïtiques dispersés III," 21-23).

14 Brock, "Syriac Manuscripts Copied on the Black Mountain," 63. 
Hence, Syriac Rum Orthodox monks probably donated the SGP along with the many other Syriac and Christian Arabic manuscripts that reached the monastery in the same period. During the thirteenth century, the monastery received a large number of foreign pilgrims from various parts of the Mediterranean basin and witnessed a vast influx of monks, especially from the Levant. ${ }^{15}$ It was this period that witnessed the formation of a substantial part of the monastery's manuscript collection.

At St. Catherine's, the SGP could still have been used by the Aramaicspeaking monks. The monks, however, were not in a position to use all the liturgical manuscripts in their possession, so some of them were put into storage. ${ }^{16}$ By the fifteenth to the sixteenth centuries, the monastery had become nearly entirely Greek-speaking, so all the Syriac manuscripts (including those that had been in use) were likewise put into storage. Since the manuscript was brought to the monastery of St. Catherine after it had already been recycled, the chances of finding the missing parts remain remote. ${ }^{17}$

Many of the manuscripts were kept in a storeroom located in the tower of St. George in the northern wall of the monastery. In 1734, Archbishop Nikiphoros Marthales reorganized the library, and most of the manuscripts were transferred to a newly constructed building. Many worn books and loose leaves were left behind, and the storeroom was forgotten for more than two centuries. ${ }^{18}$ In 1975 , while clearing debris caused by a fire, the

15 It is unclear why, but it has been suggested that it may relate to the advance of the Mamluks; see N. P. Ševčenko, "Manuscript Production on Mount Sinai from the Tenth to the Thirteenth Century," in Approaching the Holy Mountain: Art and Liturgy at St. Catherine's Monastery in the Sinai, ed. S. E. J. Gerstel and R. S. Nelson (Turnhout: Brepols, 2010), $233-58$ at 250 .

16 One should not forget that Syriac manuscripts were also copied on Sinai, and the thirteenth century is particularly significant in that regard, with some forty known manuscripts; see S. P. Brock, "Syriac on Sinai: The Main Connections," in EYKO $M I A$ : Studi miscellanei per il $75^{\circ}$ di Vincenzo Poggi S.J., ed. V. Ruggieri and L. Pieralli (Catanzaro: Rubbettino, 2003), $103-17$ at $113-16$.

17 The ongoing Sinai Palimpsest Project aims at making available a large number of palimpsests from the Sinai library; however, no traces of the medical manuscript used for the production of the SGP have been discovered. See C. Rapp and M. Phelps, "The Sinai Palimpsests Project," Sinaiticus: The Bulletin of the Saint Catherine Foundation (2017): 18-20.

18 For the history of the library and its new finds in particular, see P. Géhin, "La bibliothèque de Saint-Catherine du Sinaï: fonds ancien et nouvelles découvertes," in Le Sinaï durant 
monks discovered a blocked room filled with manuscripts and fragments, including one folio of the SGP (namely, NF Syr. Sparagma 65). ${ }^{19}$

Although the monastery of St. Catherine was highly esteemed throughout its history, from the seventeenth century it became a special attraction for European scholars and collectors searching for ancient manuscripts. Scholars began to catalog its holdings in the nineteenth century, particularly with the efforts of Agnes Smith Lewis (1843-1926) and Margaret Dunlop Gibson (1843-1920), who worked on its Syriac, Christian Arabic, and Christian Palestinian Aramaic manuscripts. ${ }^{20}$ Significantly, the SGP does not feature among the Syriac manuscripts, which Lewis cataloged in 1893; therefore, the SGP must have been removed from the monastery beforehand. $^{21}$

We do not know, however, how the SGP disappeared from the monastery and eventually ended up in the lot of Syriac Rum Orthodox manuscripts offered for sale in 1922 in Leipzig by the manuscript dealer Karl W. Hiersemann. Nevertheless, we do know who possessed the loose leaves that once belonged to the SGP. Friedrich Grote, an enigmatic connoisseur of the Sinai Peninsula and Egyptian libraries, and missionary to the Bedouins, compiled a substantial collection of Christian Oriental manuscripts originating from Sinai, although how he assembled them is unclear. In the year 1894, Grote enjoyed fleeting fame for discovering a number of invaluable

l'Antiquité et le Moyen Age: 4000 ans d'Histoire pour un désert, ed. D. Valbelle and C. Bonnet (Paris: Errance, 1998), 157-64; P. Koufopoulos and M. Myriantheos-Koufopoulou, "A History of the Library at the Monastery of Sinai," Sinaiticus: The Bulletin of the Saint Catherine Foundation (2017): 21-23.

19 S. P. Brock, “The Syriac 'New Finds' at St Catherine's Monastery, Sinai, and Their Significance," The Harp 26 (2011): 39-52.

20 G. R. Parpulov, "The Greek and Latin Manuscripts of Mount Sinai and the Scholarly World," in St. Catherine's Monastery at Mount Sinai: Its Manuscripts and Their Conservation, ed. C. Mango et al. ([London]: Saint Catherine Foundation, 2011), 35-42. For biographies of Lewis and Gibson, see J. Soskice, Sisters of Sinai: How Two Lady Adventurers Found the Hidden Gospels (London: Chatto and Windus, 2009); R. J. W. Jefferson, "Sisters of Semitics: A Fresh Appreciation of the Scholarship of Agnes Smith Lewis and Margaret Dunlop Gibson," Medieval Feminist Forum: A Journal of Gender and Sexuality 45 (2009): 23-49.

21 A. S. Lewis, Catalogue of the Syriac Mss. in the Convent of S. Catharine on Mount Sinai, Studia Sinaitica 1 (London: Clay and Sons, 1894). 
Syriac, Arabic, and Christian Palestinian Aramaic manuscripts. News spread rapidly from Cairo all the way to Tokyo. Reportedly, Grote was planning to publish his findings, but he never did. Grote subsequently permitted interested scholars to study some of his manuscripts and also started to sell them - a process that was continued by his widow after his death in 1922. ${ }^{22}$ Grote's manuscripts and fragments can today be found in various locations, including the Vatican Library, the French National Library, the Bavarian State Library, the Houghton Library at Harvard, Göttingen University Library, and the Schøyen Collection. ${ }^{23}$ These include five folios that originally belonged to the SGP: ${ }^{24}$

Rome, Vatican Library, Vat. sir. 647, fols. 38-39

Paris, Bibliothèque nationale de France (BnF), MS syr. 382, fol. 10

Cambridge, Massachusetts, Houghton Library (Harvard), MS Syriac 172, fol. 1

Rome, Vatican Library, Vat. sir. 623, fol. 227

Grote may have split up some of the manuscripts or leaves in his possession, as appears to be the case for the last two leaves listed above. Another manuscript collector, Otto F. Ege (1888-1951), proceeded in a similar fashion: he disbound manuscripts and sold them in specifically arranged folders with the altruistic idea of making beautiful medieval book art accessible to the masses. Further research into Grote's life may shed additional light on his motivations. ${ }^{25}$

22 For the fragment preserved in Harvard University Library, see G. Kessel, "Membra disjecta sinaitica II: Three Syriac Fragments in the Harvard Library," Harvard Library Bulletin 25, no. 3 (2014 [2016]): 30-54.

23 On Grote, see G. Kessel, "Membra disjecta sinaitica I: A Reconstitution of the Syriac Galen Palimpsest," in Manuscripta Graeca et Orientalia. Mélanges monastiques et patristiques en l'honneur de Paul Gébin, ed. A. Binggeli et al., Orientalia Lovaniensia Analecta 243 (Leuven: Peeters, 2016), 469-96 at 482-86.

24 For a more detailed discussion of the fragments, see Kessel, "Membra disjecta sinaitica I," 473-82.

25 Peter Tarras (University of Munich) has kindly informed us that he is preparing an article on Grote's life. 
The history of the SGP in Europe is better known. It was first purchased by the textile industrialist (and later Nazi supporter) Arnold J. MettlerSpecker (1867-1946) of St. Gallen, Switzerland. ${ }^{26}$ In the 1920s, he deposited it, along with the rest of his manuscript collection, in the Zentralbibliothek, Zurich, with the signature Zürich Or. 77. Mettler-Specker withdrew his collection from the Zentralbibliothek on 9 March 1942, and handed it over to the Vadiana library in St. Gallen. Following his death, and after the end of World War II, his heirs auctioned off most of his manuscripts, apparently including the SGP, in New York on 29-30 November 1948..$^{27}$ In the United States, the manuscript probably changed hands a couple of times until it was sold at auction in Los Angeles in October 2001. In March 2002 it was purchased by its current owner.

\section{The Content of the Overtext}

The upper text of the palimpsest contains a Syriac translation of the complete hymnographic book of the Eastern Christian tradition (Byzantine rite) traditionally called Paraklêtiké (Supplicatory); it consists of a collection of

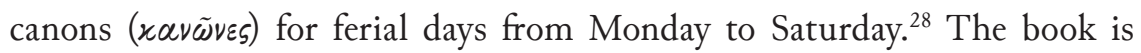

26 See T. Metzger, Antisemitismus in der Stadt St. Gallen, 1918-1939 (Freiburg: Academic Press, 2006), 382-88.

27 Six manuscripts from Mettler-Specker's collection were left unsold following this auction, and were returned to St. Gallen. These were eventually acquired from Mettler-Specker's heirs by the University of Leiden in 1974. See T. Nünlist, Katalog der Handschriften der Zentralbibliothek Zürich Band IV: Arabische, türkische und persische Handscbriften (Wiesbaden: Harrassowitz, 2008), xix-xx; W. Strothmann, "Die orientalischen Handschriften der Sammlung Mettler (Katalog Hiersemann 500)," in XIX. Deutscher Orientalistentag vom 28. September bis 4. Oktober 1975 in Freiburg im Breisgau, ed. W. Voigt (Wiesbaden: F. Steiner, 1977), 285-93 at 287-88.

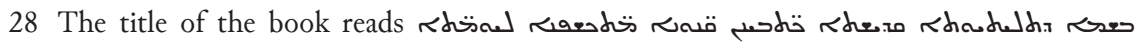
عنتصن (In the name of the Holy Trinity we write supplicatory canons of the weekdays) (Vat. sir. 647, fol. 38r). The text was first identified as the Melkite liturgical book Paraklètiké by Anton Baumstark in K. W. Hiersemann, Katalog 500: Orientalische Manuskripte (Leipzig: Hiersemann, 1922), 14 and appendix. Kessel, "Membra disjecta sinaitica I," 471-72, previously summarized Baumstark's findings and expanded on them. 
organized in eight equal parts according to the ecclesiastical Oktốéchos (eight modes) with reference to both the system of eight modes (four authentic and four plagal) used in the church music and the eight-week cycles that form the ecclesiastical year.

The canon is a hymnographical composition closely associated with, and built around, the nine Biblical Odes (the Canticles), poetical texts in the form of a prayer or a praise to God taken from the Old and New Testaments. For instance, in Eastern Christianity, the following series of nine odes was used:

1. First Song of Moses (Exodus 15:1-19)

2. Second Song of Moses (Deuteronomy 32:1-43)

3. Prayer of Hannah, the mother of Samuel (1 Samuel 2:1-10)

4. Prayer of Habakkuk (Habakkuk 3:1-19)

5. Prayer of Isaiah (Isaiah 26:9-19)

6. Prayer of Jonah (Jonah 2:3-10)

7. Prayer of Azariah (Daniel [LXX] 3:26-56)

8. Song of the Three Young Men (Daniel [LXX] 3:57-88)

9. The Magnificat, Prayer of Mary (Luke 1:46-55) and Song of Zechariah (Luke 1:68-79), two odes traditionally united in one.

A fifth-century biblical manuscript, BL Royal $1 \mathrm{D}$ V-VIII, also known as the Codex Alexandrinus, provides the earliest evidence of the inclusion of fourteen Biblical Odes in a separate section after the Psalms, apparently for liturgical use. ${ }^{29}$

The genre of the hymnographical canon developed from adding short refrains and, later, metrical strophes (tropária) to each of the Canticles. These sets of tropária received the name ode (ōidế), as they were sung during the service of Matins along with the Biblical Odes and gradually replaced the latter. The newly composed hymns, however, were closely dependent on the Greek text of their prototypes (most commonly, the Septuagint) in terms of content, phraseology, and metrical composition. One of the earliest

29 On fols. $564 \mathrm{v}-569 \mathrm{r}$. 
examples of a canon has been identified in a seventh-century Fayum papyrus in the John Rylands Library (P. Ryl. 466). It contains a canon composed of two odes (dióidion), which in turn are formed of four-strophe tropária on

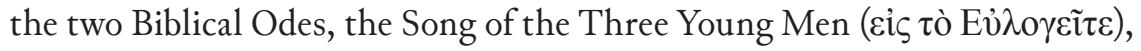

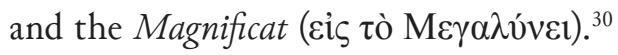

By the end of the seventh century, a standard set of the nine Canticles had been established for liturgical recitation and singing and, as a reflection of this practice, the canon composed of nine odes (in its complete form) had been formed. The tradition ascribes this to Andrew, the Archbishop of Crete (d. ca. 740), although modern scholars argue that this might have been his contemporary Germanus, the Archbishop of Constantinople (d. ca. 733) who first composed the nine-ode canons. ${ }^{31}$ Another important modification to the canon that took place presumably during the seventh century was the introduction of the heirmoi (sing. heirmós). This is the first stanza of each ode, which provides close textual connection with the Biblical Ode and serves as a metrical pattern for the subsequent tropária. At some point before the tenth century, the second ode in the hymnographical canon started being dropped and then was sung only on a few occasions during the ecclesiastical year. Among Byzantine hymnographers who contributed to the development of the canon were John of Damascus (d. ca. 749) and Cosmas of Mayuma (second half of the eighth century) in Jerusalem, then Theodore of Stoudion (d. 826), Joseph the Hymnographer (d. ca. 886), and Theophanes Graptos (d. 845) in Constantinople. Their names are present either in the headings of the canons and their acrostics, or in some cases, in the colophons of the liturgical manuscripts.

The canons constitute an essential part of many service books in the Eastern Christian tradition, one of which is the book of Octốéchos. It developed from an older Greek hymnographic book called Tropológion (the Book of Tropária), first in Palestine, then in Constantinople, and underwent a

30 C. H. Roberts, ed., Catalogue of the Greek and Latin Papyri in the Jobn Rylands Library Manchester, vol. 3: Theological and Literary Texts (nos. 457-551) (Manchester: Manchester University Press, 1938), 28-35.

31 M. Velimirović, "Kanōn,” Grove Music Online, https://doi.org/10.1093/gmo/9781561592 630.article.14677, accessed 16 March 2018. 
number of transformations in the course of its history. Thus the Old Palestinian Octóéchos of the late eighth and early ninth centuries (Sinai, St. Catherine's Monastery, Sinait. gr. 776 and 1593, and BL Add. 26113) was organized systematically and contained sets of hymns of different genres including stichērá, kathísmata, "common" (koinoí) Sunday canons ascribed to John of Damascus and "supplicatory” (paraklētikoí) weekday canons. Within each genre, the hymns were divided into eight modes.

Further developments in the structure and contents of the book of Octốéchos took place in Constantinople, as reflected in the Typiká of the Stoudion Monastery (late ninth or early tenth century) and the Monastery of the Mother of God Evergetis (second half of the eleventh century), apart from the numerous liturgical manuscripts. The genre organization gave way to the more complex structure set down according to the service order for every day of the week. At this stage, further canons ascribed to the Constantinopolitan hymnographers were added to the Octóéchos, which then spread widely throughout the Byzantine commonwealth.

The Syriac Melkite tradition reflects both stages in the development of the Octốéchos. The earliest evidence is provided by a relatively small number of manuscripts from the eleventh century. Although they all follow the eight-part structure of the Octốechos, they are quite different in content. ${ }^{32}$ For example, one of the earliest known Melkite Octốechoi, BL Add. 17133, presumably of the eleventh century, contains stichèrá, kathísmata, and Sunday canons ascribed to John of Damascus and Cosmas of Mayuma. ${ }^{33}$

Another type of Octóéchos from the early period is demonstrated by the SGP, which contains canons for weekdays. Within the manuscript, there are eight divisions, modes (قلم [voices]). ${ }^{34}$ In each mode, there are six sections

32 N. Smelova, “After the Order of Melchizedek': Materials for the Classification of the Melkite Syriac Octoechos," in Studies in the Cultural Traditions of the East: Hebrew-GreekSyriac-Slavonic, ed. C. von Buettner and N. Smelova (St. Petersburg: St. Petersburg Institute of Jewish Studies, 2016), 229-48 (in Russian).

33 W. Wright, Catalogue of the Syriac Manuscripts in the British Museum, Acquired Since the Year 1838 (London: Trustees of the British Museum, 1870), 1:324.

34 Mode 1: Vat. sir. 647, fol. 38r; mode 2: SGP fol. 32v; mode 3: SGP fol. 63r; mode 4: BnF syr. 382, fol. 10v; mode 5: SGP fol. 120r; mode 6: SGP fol. 147v; mode 7: SGP fol. 174v; mode 8: SGP fol. 201r. 
corresponding to six days of the week, Monday to Saturday. For each day there are either one or two "supplicatory" canons (قصم م تصحص). The canons have different dedications depending on the day of the week (Monday, on Penitence and to the Angels; Tuesday, to John the Baptist; Wednesday, to the Mother of God; Thursday, to the Apostles; Friday, to the Cross; Saturday, to the Departed). A partially similar order of dedications can be found in a number of Greek manuscripts, including Sinai, St. Catherine's Monastery, Sinait. gr. 794 (tenth century). It is thought to reflect the Constantinopolitan tradition and contain the canons ascribed to Joseph the Hymnographer and Theophanes. ${ }^{35}$ There is a possibility, however, that at least some "supplicatory" canons in the SGP belong to the Palestinian tradition (cf. Sinai, St. Catherine's Monastery, Sinait. gr. 776).

All canons in the SGP lack the second ode and the full text of heirmoí. The latter is not surprising, since Joseph the Hymnographer is known not to have composed original beirmoí for his canons but used the existing model stanzas, which by that time would be gathered in hymnographic appendices or even separate books called Heirmológia. ${ }^{36}$ However, for most odes in the SGP, the indication of the model stanza is provided in the heading. ${ }^{37}$ Each canon thus consists of eight odes, and each ode in turn is composed of up to five tropária.

Liturgical manuscripts from the early period are not particularly numerous, and it is rare for both traditions, Greek and Syriac, to have two or more manuscripts identical (or almost identical) in structure and contents. In the

35 I. E. Lozovaya, The Twelfth-Century Old Russian Parakletike with Notation: Its Byzantine Sources and the Typology of Its Old Russian Manuscripts (Moscow: Moscow State Conservatory, 2009), 38-55 (in Russian).

36 Rev. V. A. Rybakov, Saint Joseph the Hymnograber and His Hymnographic Legacy (Moscow: Russkaya Kniga, 2002), 366 (in Russian). On Heirmologion, see M. Velimirović, "Heirmologion [hirmologion]," Grove Music Online, https://doi.org/10.1093/gmo/9781561592630. article.12715, accessed 16 March 2018.

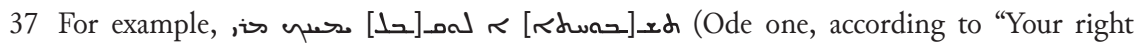

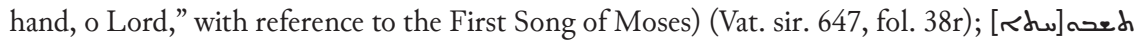

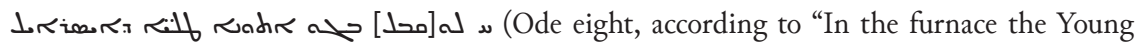
Men of Israel," with reference to the Song of the Three Young Men) (SGP, fol. 6r). The model indications are not provided for the second Monday canon (to the Angels) because it is supposed to follow the same metrical pattern as the first Monday canon (on Penitence). 
case of the SGP, however, we are fortunate to have another example of the same type of Octóéchos, presumably from the same period. This is the manuscript BL Add. 14510, copied in 1056 CE (AG 1367) in the Monastery of the Prophet Elias on the Black Mountain in Antioch by the priest Peter, also known as Polycarpus, son of Joseph. It was commissioned by the abbott Simeon, son of Abraham, from Maipherkat. The later notes in Arabic and Christian Palestinian Aramaic provide the information that the manuscript was purchased by a deacon Surūr in the village Minyat Zifta near Cairo. He characterizes the contents as "Syro-Edessan canons." ${ }^{8}$ This case provides yet more evidence for our assumption that the palimpsest is closely connected to the Black Mountain and probably originates from this region. The only structural difference between the two manuscripts is that the British Library manuscript has an appendix containing makarismoi, the hymns sung in conjunction with the New Testament Beatitudes, for eight modes and for each day of the week, including Sundays. The presence of a few empty leaves in the last quire of the SGP suggests that it was left unfinished by the scribe, as both the appendix and the colophon would be appropriate for a manuscript of this type.

\section{Codicology and Paleography of the Secondary Manuscript}

The manuscript that we call the Syriac Galen Palimpsest is obviously a secondary production, in the sense that the original manuscript was reused to create this second or subsequent manuscript. The latter consists of 231 folios: the bound palimpsest now owned privately (225 folios), and the six further individual leaves identified by Grigory Kessel in different libraries. ${ }^{39}$ The dimensions of the bound manuscript are $175 \times 127$ millimeters.

38 Wright, Catalogue of the Syriac Manuscripts, 1:379. See also Hatch, An Album of Dated Syriac Manuscripts, pl. cxxii, p. [173]; Brock, "Syriac Manuscripts Copied on the Black Mountain," 62-63.

39 These are (according to the sequence of the overtext) Vat. sir. 647, fols. 38-39; Sinai Syr. NF, Sp. 65, fol. 1; BnF syr. 382, fol. 10; Houghton Library syr. 172, fol. 1; Vat. Sir. 623, fol. 227. See Kessel, "Membra disjecta sinaitica I," 469-96, and earlier in the present paper. 
124 | Journal For Manuscript Studies

\section{QUIRES}

The bound codex is organized in twenty-nine quaternions (quires of eight folios, or four bifolia) that are completed by the six individual folios in other collections. ${ }^{40}$ The quires do not demonstrate a consistent folding pattern: some of them follow Gregory's Rule-that is, the flesh side of the parchment faces the flesh side, and the hair side faces the hair side, as in quire 1, from Vat. sir. 647, folio 38, to SGP folio 6. In some others, the hair and flesh sides strictly alternate, as is the case for instance in quire 6, from SGP folio 39 to SGP folio 46. In most quires, however, the order is mixed. The folios previously marked as orphans (fols. 223, 226) or singletons (fols. 224, 225) in fact make up two bifolia, folios 223-26 and 224-25, but are broken in half; they both belong to the last quire. Only one folio (222) has been definitely identified as a singleton, as its second half is missing and apparently was not used in the palimpsest. The quire signatures in Syriac and Greek are present throughout the manuscript. Two identical Syriac numbers in a line-and-dots ornament are placed at the bottom of the first and last pages of the quire. The Greek numbering appears in the top left corner on the first pages only.

\section{TeXt Layout}

The overtext is laid out in one column per page. The ruling was made with a dry hard point and is perfectly traceable throughout the manuscript. It marks the horizontal and vertical borders of each column. In many cases, however, the upper baseline does not sit on the ruling and goes further up with yet another line above or on the border. Likewise, up to two lines usually go beyond the lower border. Although the mean area of ruling is $117 \times 85$ millimeters, the actual writing area may be more extensive, up to $137 \times 90$ millimeters; the height is measured from baseline to baseline and the width from the farthest point to the farthest point. The number of lines

40 See the collation chart in Kessel, "Membra disjecta sinaitica I," 481-82. 
per page is variable, normally between eighteen and twenty-three. The vertical justification is not strictly observed either on the right- or the lefthand side. Some cases of discrepancy in the ruling pattern can be found, for example on folios 224-25, where the ruling was done twice horizontally and three times vertically, perhaps because the earlier efforts were flawed; this may explain why this bifolium was the last to be used and has been left partially blank.

\section{The Palimpsest}

Of approximately twenty-two quinions of the original Galen codex, only fourteen were used to make the secondary manuscript (for details, see below). The original bifolia were detached, and its text was washed away with an acid solution. The bifolia were cut in half, rotated 90 degrees, and folded again. As the manuscript was bound and rebound, some minimal trimming might have been done on the edges. Abigail Quandt has observed a consistency in the production of the palimpsest: most of the original folios were placed in such a way that the fold and the gutter would make the bottom edge of the secondary manuscript. Thus the top margin of the original rectos would be on the right-hand side, while that of the versos would be on the left. ${ }^{41}$ Based on the information provided by the codicological reconstruction of the original medical manuscript, Quandt made an assumption that a number of quires from the beginning, the end, and the very middle of the codex could have been damaged or missing prior to this process. Therefore, one of the reasons for its recycling might be that the Galen codex was already damaged from the outset and therefore unusable. ${ }^{42}$

41 See A. Quandt and R. Wolcott, "The Codicology and Conservation of the Syriac Galen Palimpsest," in the present volume. There are a number of exceptions to this rule found throughout the manuscript, where the fold and the gutter are oriented upwards-e.g., fols. $102-7,103-6,104-5$ (all three within the same quire), 118-23, 136-37, 150-55, 152-53, 184-85, and 199-202.

42 Quandt and Wolcott, "The Codicology and Conservation of the Syriac Galen Palimpsest." 


\section{Paleography}

The overtext is written in a Melkite hand-the type of writing that was in use in Chalcedonian (Rum Orthodox) communities. The script is mostly based on the monumental estrangelo writing with elements of cursive (dālat, $b \bar{e}, r \bar{s} s$ ), while some other characters ( $\bar{a} l \bar{a} \bar{p}, k \bar{a} \bar{p}$, final lammad, mìm, taw) can take both forms. Another distinct feature of the Melkite writing is that some letters may appear in a transitional shape that is neither monumental nor cursive in the strict sense (waw, mìm, final nün, taw).

Above, we drew a parallel between the SGP and another Melkite manuscript, BL Add. 14510, produced in 1056, which is particularly close in terms of its contents. The two manuscripts also share the same type of writing, common to other dated manuscripts copied on the Black Mountain in Antioch during the eleventh century. ${ }^{43}$ Other shared features include the quire composition (quaternions) and the text layout (one column). ${ }^{44}$ There are, however, some differences between the two manuscripts in terms of paleography and codicology. The ruling of the BL manuscript consists of a grid marking every single line, with traces of pricking clearly visible throughout. The page layout is more regular, with twenty lines per page, while the number of lines in the SGP varies, as does the surface area of writing. Finally, the BL manuscript uses polychrome ornaments marking the modes and days of the week, while the SGP has no ornamentation except for the red ink used in the headings.

The BL manuscript is equally unusual in terms of codicology. The signatures in Syriac are typically placed at the top of the last page in a quire (sometimes also on the first page). The numbering comes up to quire 18 at the end of the fourth mode and, again, at the end of the eighth mode, and then starts again from quire 1 at the beginning of the fifth mode and the beginning of the appendix. However, the manuscript is definitely a single codicological structure and is written in one hand.

43 Another case of manuscript from the Black Mountain similar to the SGP in the style of writing is BL Add. 14489, copied in 1045, as described above. However, the BL manuscript has a different text layout, as it is written in two columns, in contrast to one column in the SGP. See Hatch, An Album of Dated Syriac Manuscripts, pl. clxxxiv, p. [235].

44 Hatch, An Album of Dated Syriac Manuscripts, pl. cxxii, p. [173]. 
Therefore, although the two Melkite manuscripts are very close to each other in the principal aspects, the ruling and the quire numbering are different. Moreover, both manuscripts were produced using inferior parchment. The scribe of the BL manuscript used pieces of parchment of different quality; some leaves are particularly thin and white (probably made of calfskin), while other leaves are thicker, most of them are roughly made and cut. Numerous defects testify that the parchment is probably an offcut. The SGP, in turn, produced by means of recycling, might belong to a somewhat later period when the availability of parchment became even more problematic and the palimpsesting technique had to be employed in order to create a liturgical manuscript for the monastic community. If Grigory Kessel is right and the SGP originates in the monastery of the Prophet Elias on the Black Mountain near Antioch, then it would be a unique example of a palimpsest produced there presumably during the second half of the eleventh century. ${ }^{45}$ Abigail Quandt discerned a lack of the practice in disassembling manuscripts and reusing them in the community where the SGP was produced, as the SGP has been put together in a much more irregular and unsystematic manner than other palimpsests, including the Archimedes one, that were produced by more professional workshops. ${ }^{46}$

\section{The Contents of the Original Medical Manuscript}

The original medical manuscript contains a Syriac translation of Galen's main pharmacological treatise, On the Mixture and Power of Simple Drugs

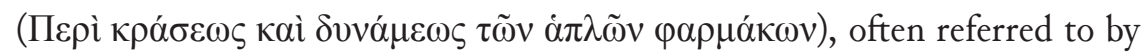
its Latin title, De simplicium medicamentorum temperamentis ac facultatibus. ${ }^{47}$

45 See Kessel, "Membra disjecta sinaitica I," 483.

46 Quandt and Wolcott, "The Codicology and Conservation of the Syriac Galen Palimpsest."

47 C. G. Kühn, Claudii Galeni, Opera omnia I-XX (Leipzig: prostat in officina libraria Car.

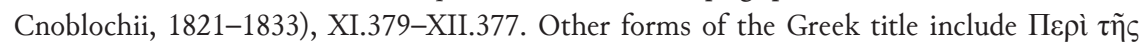

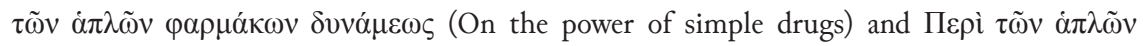

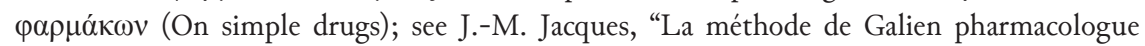
dans les deux traités sur les médicaments composés," Galen on Pharmacology: Philosophy, History and Medicine, ed. A. Debru (Leiden: Brill, 1997), 103-29 at 123 n. 70. 
It comprises eleven books that cover a variety of topics: Books 1 to 5 deal with the theory of simple drugs, and Books 6 to 11 tackle practical aspects and comprise alphabetical lists. From BL Add. MS 14661, we know that one

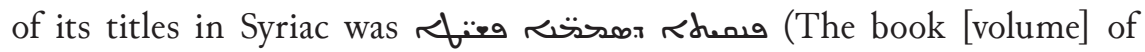
simple drugs). ${ }^{48}$ In Arabic, it had various titles, including كتاب الأدوية المفردة and كتاب الأدوية البسبطة, both meaning "The book of simple drugs," and the shorter كتاب البساط (The book of simples). ${ }^{49}$ We shall refer to it in this article, therefore, as the Book of Simple Drugs, because this is how it was most often known in Syriac and Arabic.

For Books 6 to 8, the SGP preserves the same translation by Sergius of Rēš 'Aynā as Add. MS 14661. Sergius studied medicine and philosophy in Alexandria, where the Neoplatonic reception of Aristotle dominated. As we know from the later Arabic sources, the medical curriculum in Alexandria included four books by Hippocrates and sixteen books by Galen. ${ }^{50}$ Galen's Book of Simple Drugs was not included in the Alexandrian canon, so it numbers among those Galenic works that Sergius translated over and above what was prescribed in Alexandria. Sergius's motivations for going beyond the Alexandrian canon probably relate to his overall approach to education, which very much expanded his understanding of what was essential in medicine and pharmacology, and which included much that was considered theoretical and of less practical value for physicians. ${ }^{51}$ Thus, in his introduction to Book 6, Sergius not only advocates philosophy as "general" knowledge, but also summarizes the philosophical concepts set out in the preceding five books. In particular, following Galen, he refutes the atomism of the followers of Leucippus and Democritus, and expounds the Aristotelian

48 Taken from manuscript BL Add. 14661, as edited by A. Merx, "Proben der syrischen Uebersetzung von Galenus' Schrift über die einfachen Heilmittel," Zeitschrift der Deutschen Morgenländischen Gesellschaft 39 (1885): 237-305 at 244.

49 For the Arabic titles, see M. Ullmann, Die Medizin im Islam (Leiden: Brill, 1970), 47.

50 See E. Lieber, "Galen in Hebrew: The Transmission of Galen's Works in the Mediaeval Islamic World," in Galen: Problems and Prospects, ed. V. Nutton (London: The Wellcome Institute for the History of Medicine, 1981), 167-86.

51 For further details, see S. Bhayro, "Sergius of Rēš 'Aynā’s Syriac Translations of Galen: Their Scope, Motivation, and Influence," Bulletin of the Asia Institute, n.s. 26 (2012): 121-28. 
notion of four elements that constitute all things, including simple drugs. Hence all drugs are said to consist of elemental qualities- heat and cold, and moisture and dryness - which can vary by degree. These qualities determine the powers or capacities (dunámeis) of simple drugs in their mixtures, depending on which prevails.

The SGP contained at least Books 2 to 9 of Galen's Book of Simple Drugs. ${ }^{52}$ It therefore provides evidence that the whole work was transmitted in the Syriac tradition. This contrasts with what was previously known about its transmission, as Hunayn clearly separates the translation history of the first (theoretical) and second (practical) part, almost as if the two were circulating independently. Hunayn claimed that he translated the first part for Salmawayh ibn Bunān, and corrected Sergius's translation of the second part for Yūḥannā ibn Māsawayh. In the later version of Hunayn's Risāla (Istanbul, Süleymaniye Kütüphanesi, MS Ayasofya 3631, fol. 16v), the Arabic translation of the whole work is ascribed to Hubayš ibn al-Hasan. A note in a different hand reads that Hunayn later epitomized the whole work in Syriac, and translated the first part of it into Arabic for 'Alī ibn Yahyā, the addressee of the Risāla. ${ }^{33}$

The manuscript evidence analyzed by Manfred Ullmann, however, provides a different perspective on the Arabic tradition of Galen's Book of Simple Drugs. Ullmann demonstrates clearly that the Arabic version of all eleven books preserved in MS Escorial 793 (Books 1 to 11) and MS Escorial 794 (Books 6 to 11) is Hunayn's translation and not that of Hubaysh. ${ }^{54}$ Furthermore, while the text of Book 6 in Istanbul, Süleymaniye Kütüphanesi, MS Saray Ahmet III 2083, represents the earlier translation by al-Bițrīq, which is otherwise known from quotations in Maimonides and other Arabic writ-

52 At the time of writing, three folios remain unidentified: $031 \mathrm{r} / \mathrm{v}-038 \mathrm{v} / \mathrm{r}, 143 \mathrm{r} / \mathrm{v}-146 \mathrm{v} / \mathrm{r}$, and $191 \mathrm{r} / \mathrm{v}-194 \mathrm{v} / \mathrm{r}$.

53 See G. Bergsträsser, Hunain ibn Ishāq über die syrischen und arabischen Galenübersetzungen, Abhandlungen für die Kunde des Morgenlandes 17, no. 2 (Leipzig: Brockhaus, 1925), r., 24; J. C. Lamoreaux, Hunayn Ibn Isḥāq on His Galen Translations, Eastern Christian Texts 3 (Provo, UT: Brigham Young University Press, 2016), 68 n. 9.

54 M. Ullmann, Wörterbuch zu den griechisch-arabischen Übersetzungen des 9. Jabrbunderts (Wiesbaden: Harrassowitz, 2002), 32-35. 
ers, all the other books pertain to Hunayn's translation..$^{55}$ In what appears to contradict his bibliographical notice in the Risāla, therefore, Hunayn's Arabic text testifies to the unity of the treatise.

Turning to the Byzantine tradition, we observe here, too, that Galen's Book of Simple Drugs is divided into two parts, as is the case in Rome, Vatican Library, Vat. gr. 284, the earliest surviving Greek manuscript of this work. Tentatively dated to the tenth century, it contains the text of the second part, Books 6 to 11, with additions from Dioscorides's On Medicinal

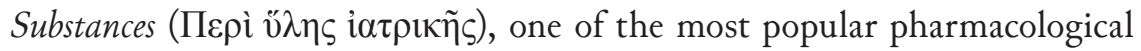
texts. It should be noted, however, that in the Syriac tradition no such additions of Dioscorides to Galen's text have come to light. Only one manuscript attests to the fact that the whole of On Simple Drugs was transmitted as a single work, and this is Milan, Biblioteca Ambrosiana, MS A 81 inf. (gr. 802), a fragmentary codex dating to the first half of the thirteenth century, which contains parts of Books 5 to 9 written in the same hand. ${ }^{56}$ Brigitte Mondrain and Caroline Petit showed that in fifteenth-century Constantinople the two parts were reunited: Vatican Library, Urbinas gr. 67, consists of an original fourteenth-century manuscript that contained Books 6 to 11, to which a scribe in the circle of Demetrios Angelos added Books 1 to 5. ${ }^{57}$ The two parts were firmly reunited in the first printed edition, the Aldine of 1525, and in subsequent editions of Galen's Complete Works in Greek, including that of K. G. Kühn. ${ }^{58}$ The SGP, therefore, constitutes an important witness that both parts of Galen's Book of Simple Drugs were transmitted in a single manuscript.

55 Ullmann, Wörterbuch, 35-41.

56 C. Petit, "Théorie et pratique: connaissance et diffusion du traité des Simples de Galien au Moyen Âge," in Fito-zooterapia antigua y altomedieval: textos y doctrinas, ed. Arsenio Ferraces Rodríguez (A Coruña: Universidade da Coruña, 2009), 79-95 at 85-86.

57 C. Petit, "La tradition manuscrite du traité des Simples de Galien: Editio princeps et traduction annotée des chapitres 1 à 3 du livre I," in Storia della tradizione e edizione dei medici greci $=$ [Histoire de la tradition et édition des médecins grecs], ed. V. Boudon-Millot et al. (Naples: M. D’Auria, 2010), 147.

58 Галทиог B: Galeni librorum pars secunda, quorum indicem VIII. pagina continet (Venice: Aldus, [1525]), 1r-86v. On the history of the Galen Aldine, see L. Perilli, "A Risky Enterprise: The Aldine Edition of Galen, the Failures of the Editors, and the Shadow of Erasmus of Rotterdam," Early Science and Medicine 17 (2012): 446-66. 
We shall now briefly describe the contents of the original medical manuscript. From the original manuscript's quire numbers (see below), we know that the first three quinions are missing. Two of these quinions probably contained Book 1, and the list of contents and beginning of Book 2. Before Book 1, an initial quire probably contained a long translator's introduction to the whole book and/or other material. The preserved text starts on folios 167v-170r with the second chapter of Book 2 (Kühn XI.462). Neither the translator's preface (if there was one) nor the list of contents of this book has survived in Syriac. Apart from the first chapter and gaps amounting to five folios, the SGP preserves Book 2, as well as all of Book 3. The latter begins with the list of contents (fols. 117r-124v, col. A, gutter-col. B) and Galen's preface (fols. 117v-124r, col. A-B; Kühn XI.540-42). ${ }^{59}$ At the beginning of Book 4 (fols. 87v-91r, col. A), the first legible line in the title intriguingly

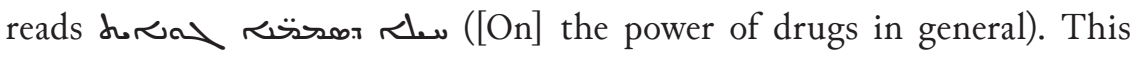
could be part of the title of Book 4, which explains the elemental qualities, or part of the title of the first chapter. The Greek manuscripts containing the list of contents of Book 4 do not shed any light on this, however, as they provide a completely different reading. ${ }^{60}$ It is possible that the adverb dora (generally) relates to the first, theoretical, part of Galen's treatise,

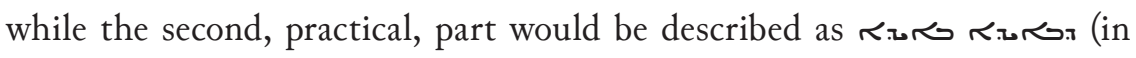
detail). ${ }^{61}$ The title is followed by the list of contents and then directly by Galen's text (fols. 87v-91r, col. B, gutter ff.; Kühn XI.619-20), with only three folios of this book missing. The list of contents of Book 5 begins on folios 175r-178v (col. B), and is followed by Galen's text (Kühn XI.704-5). The state of preservation of Book 5 is very good, with only one missing folio.

As far as we can tell, no translator's preface has been preserved for Books 3 to 5 . We would certainly expect such a preface for Book 1 . Furthermore, the preserved lists of contents do not generally accord with those attested in the Greek manuscripts. This latter point could suggest the existence of a distinct Syriac tradition, or at least another Greek tradition that only survived in

59 The start of both Books 3 and 4 is separated from the previous text by a gap of approximately two lines.

60 See, for example, BnF Grec 2170, fol. 76r.

61 Bhayro and Brock, “The Syriac Galen Palimpsest,” 38-39. 
Syriac translation. In Books 4 and 5, we have a few unclear places, marked as gaps in Table 1, where the Syriac text seems to be shorter than the Greek text in Kühn's edition. It is possible that the Greek tradition underlying the SGP either differed in having a shorter text, or itself contained lacunae.

Books 6 to 8 generally follow the BL manuscript, including Sergius's preface, the list of contents, and Galen's text. ${ }^{62}$ The SGP contains a number of significant variants, including readings that are superior to the $\mathrm{BL}$ manuscript. ${ }^{63}$ Books 6 to 8 contain a large number of lacunae, including one full quire missing in the middle of Book 6. As the codicological structure of Book 8 and the beginning of Book 9 remains unclear, it is not possible to say how many folios are missing. The end of folios 33r-36v, column A, contains the last entry in Book 8. Therefore, folios 33r-36v, column B, presumably contains the beginning of Book 9. Only a few words at the bottom of this column are readable, however, including oras (we intend to translate). In Books 6 to 8, the latter phrase appears a few times in Sergius's introductions: השת (as now we intend to trans-

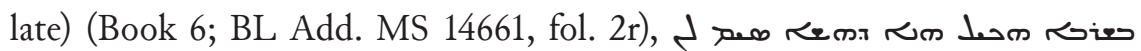

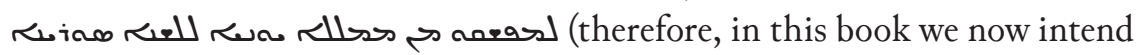
to translate from the Greek language into the Syriac tongue) (Book 6; BL

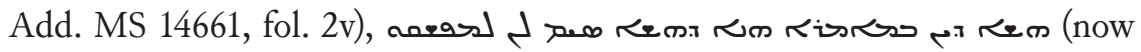
in this book we now intend to translate) (Book 7; BL Add. MS 14661, fol.

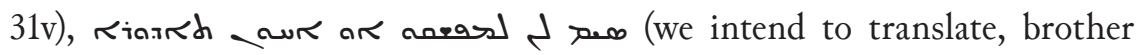

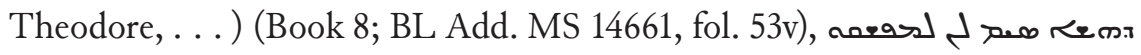
(as now we intend to translate ... ) (Book 8; BL Add. MS 14661, fol. 54v). If we manage to recover sufficient text here, we may be able to confirm that the SGP indeed contains a translator's (presumably Sergius's) preface to Book 9. The text of Book 9 presents other possibilities for in-depth research. For example, it contains an additional passage (fols. 184v-185r) concerning the old Greek letter digamma. This passage is missing from Kühn's text and,

62 See also Merx, "Proben," 249-305, and R. Hawley, "More Identifications of the Syriac Galen Palimpsest," Semitica et Classica 7 (2014): 237-72.

63 S. Bhayro et al., "The Syriac Galen Palimpsest: Progress, Prospects and Problems," Journal of Semitic Studies 58 (2013): 139-43. 
TABLE 1. The "skeleton."

\begin{tabular}{lllc}
\hline $\begin{array}{l}\text { Syriac Galen } \\
\text { Palimpsest }\end{array}$ & $\begin{array}{l}\text { Parchment } \\
\text { characteristics, } \\
\text { quires }\end{array}$ & Kübn's edition & $\begin{array}{l}\text { Book of } \\
\text { Galen's “On } \\
\text { simple drugs” }\end{array}$ \\
\hline approx. 30 folios & (quires I-III) & XI 397-458 & $\begin{array}{c}\text { One (not } \\
\text { represented) }\end{array}$
\end{tabular}

XI 459-461

Two

\begin{tabular}{|c|c|c|c|}
\hline & $167 \mathrm{v}-170 \mathrm{r}$ & hair (quire IV) & XI 462(?)-464 \\
\hline & $167 \mathrm{r}-170 \mathrm{v}$ & flesh & XI 464-466 \\
\hline \multicolumn{2}{|c|}{$r_{---}-$one folio } & & XI 466-470 \\
\hline I & $125 \mathrm{r}-132 \mathrm{v}$ & hair & XI 470(?)-472 \\
\hline$i$ & $125 \mathrm{v}-132 \mathrm{r}$ & flesh & XI 472-474 \\
\hline 1 & $10 \mathrm{r}-11 \mathrm{v}$ & hair & XI 474-476 \\
\hline I & $10 \mathrm{v}-11 \mathrm{r}$ & flesh & XI 476-478 \\
\hline 1 & $8 r-13 v$ & hair & XI 478-479 \\
\hline $\mathrm{I}$ & & & \\
\hline $\begin{array}{l}1 \\
1\end{array}$ & $8 v-13 r$ & flesh & XI 479-482 \\
\hline $\begin{array}{l}1 \\
1\end{array}$ & $127 \mathrm{r}-130 \mathrm{v}$ & flesh & XI 482-484 \\
\hline I & $127 \mathrm{v}-130 \mathrm{r}$ & hair & XI 484-485 \\
\hline i & $24 \mathrm{r}-29 \mathrm{v}$ & flesh & XI 485-487 \\
\hline i & $24 v-29 r$ & hair & XI 487-489 \\
\hline i & $50 \mathrm{v}-51 \mathrm{r}$ & Alesh & XI 489-490/491 \\
\hline I & 50,51 & ba. & YT $100 / 601$ \\
\hline i & $50 r-51 v$ & hair & X1 490/491-492 \\
\hline & -one folio & & XI 492-496 \\
\hline & $133 \mathrm{v}-140 \mathrm{r}$ & flesh & XI 496-498 \\
\hline & $133 \mathrm{r}-140 \mathrm{v}$ & hair & XI 498-500/501 \\
\hline
\end{tabular}




\section{4 | Journal for Manuscript Studies}

TABLE 1. The "skeleton" (cont.).

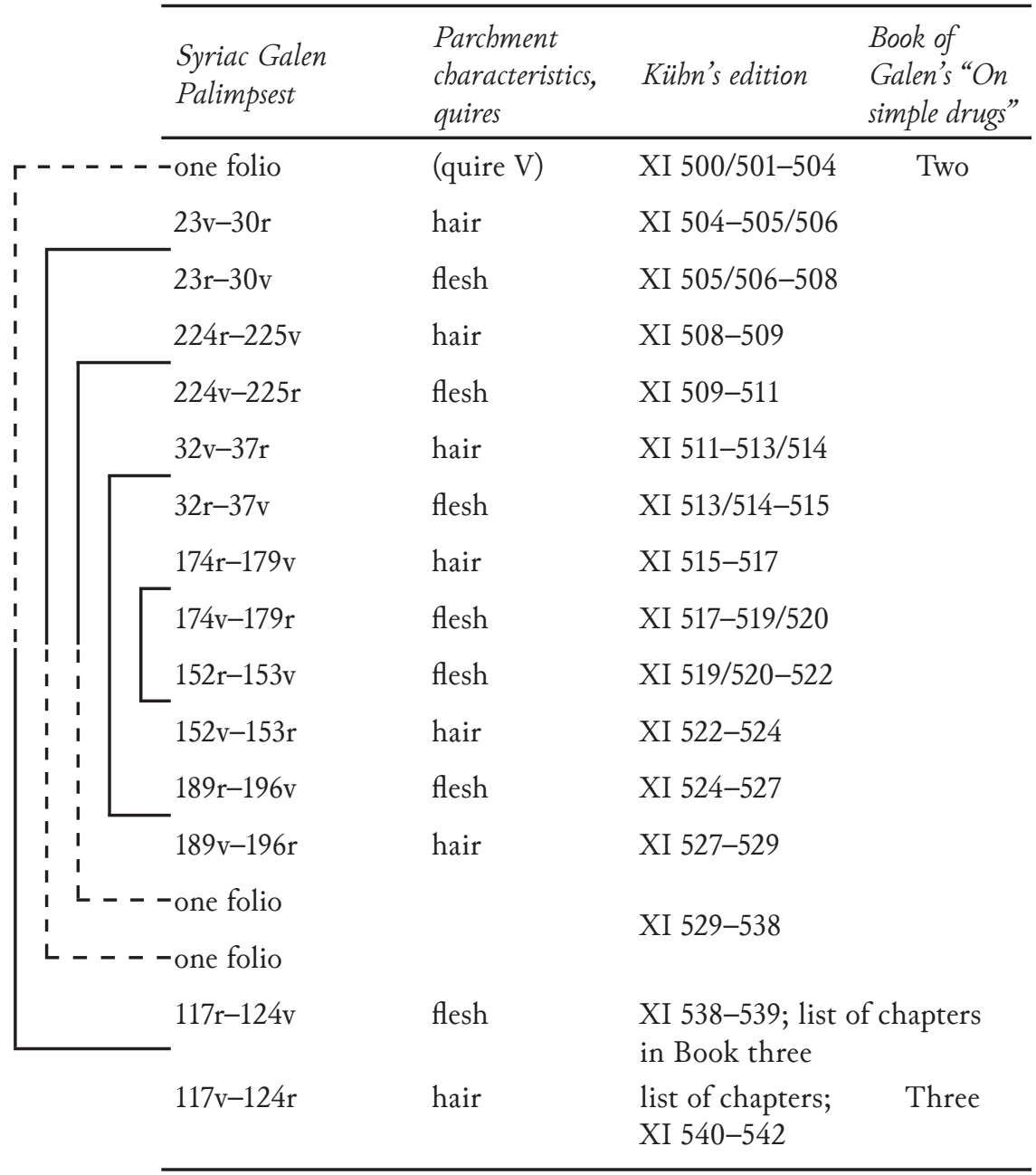

at present, is known to be preserved in one Greek manuscript, Rome, Vatican Library, Urbinas gr. $67 .{ }^{64}$ Book 9 is preserved until chapter 3 (Kühn XII.217), where the whole manuscript ends abruptly.

64 See M. Martelli, "Galeno grammatico sui nomi stranieri e il digamma: un passo inedito dal IX libro del trattato Sui medicamenti semplici," A.I.O.N.: Annali dell'Università degli Studi di Napoli "L'Orientale," Dipartimento di Studi del Mondo Classico e del Mediterraneo Antico, Sezione filologico-letteraria 34 (2012): 131-46, and our forthcoming article. 
TABLE 1. The "skeleton" (cont.).

\begin{tabular}{|c|c|c|c|}
\hline $\begin{array}{l}\text { Syriac Galen } \\
\text { Palimpsest }\end{array}$ & $\begin{array}{l}\text { Parchment } \\
\text { characteristics, } \\
\text { quires }\end{array}$ & Kübn's edition & $\begin{array}{l}\text { Book of } \\
\text { Galen's “On } \\
\text { simple drugs" }\end{array}$ \\
\hline $120 \mathrm{r}-121 \mathrm{v}$ & $\begin{array}{l}\text { hair (quire } \\
\text { VI), quire } \\
\text { signature waw }\end{array}$ & XI 542-544 & \\
\hline $120 \mathrm{v}-121 \mathrm{r}$ & flesh & XI 544-546 & \\
\hline $141 \mathrm{r}-148 \mathrm{v}$ & hair & XI 546-548 & \\
\hline $141 v-148 r$ & flesh & XI 548-550 & \\
\hline $39 v-46 r$ & hair & XI 550-553 & \\
\hline $39 r-46 v$ & flesh & XI 553-555 & \\
\hline $168 \mathrm{r}-169 \mathrm{v}$ & hair & XI 555-557 & \\
\hline $168 \mathrm{v}-169 \mathrm{r}$ & flesh & XI 557-559 & \\
\hline $134 r-139 v$ & hair & XI 559-561 & \\
\hline $134 \mathrm{v}-139 \mathrm{r}$ & flesh & XI 561-564 & \\
\hline $222 \mathrm{r}$ & flesh & XI 564-566 & \\
\hline $222 v$ & hair & XI 566-568 & \\
\hline $207 v-211 \mathrm{r}$ & flesh & XI 568-570 & \\
\hline $207 \mathrm{r}-211 \mathrm{v}$ & hair & XI 570-572 & \\
\hline $150 \mathrm{r}-155 \mathrm{v}$ & flesh & XI 572-575 & \\
\hline $150 \mathrm{v}-155 \mathrm{r}$ & hair & XI 575-577 & \\
\hline $119 \mathrm{v}-122 \mathrm{r}$ & flesh & XI 577-579 & \\
\hline $119 \mathrm{r}-122 \mathrm{v}$ & hair & XI 579-581 & \\
\hline $79 r-84 v$ & flesh & XI 581-583 & \\
\hline $79 v-84 r$ & hair & XI 583-585 & \\
\hline
\end{tabular}


TABLE 1. The "skeleton" (cont.).

\begin{tabular}{llll}
\hline $\begin{array}{l}\text { Syriac Galen } \\
\text { Palimpsest }\end{array}$ & $\begin{array}{l}\text { Parchment } \\
\text { characteristics, } \\
\text { quires }\end{array}$ & Kübn's edition & $\begin{array}{l}\text { Book of } \\
\text { Galen's “On } \\
\text { simple drugs” }\end{array}$ \\
\hline $71 \mathrm{v}-76 \mathrm{r}$ & hair (quire & XI 585-587 &
\end{tabular}

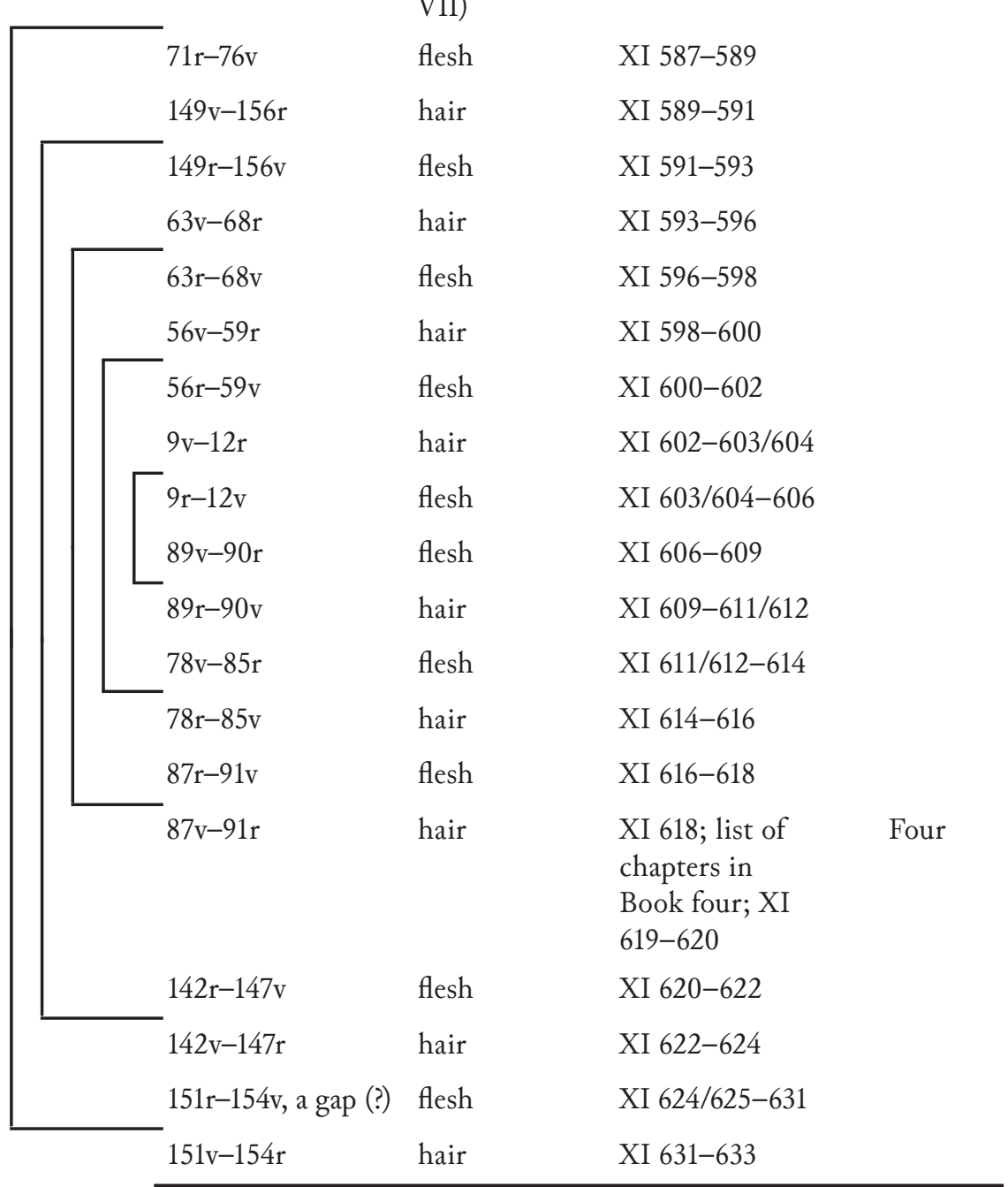


TABLE 1. The "skeleton" (cont.).

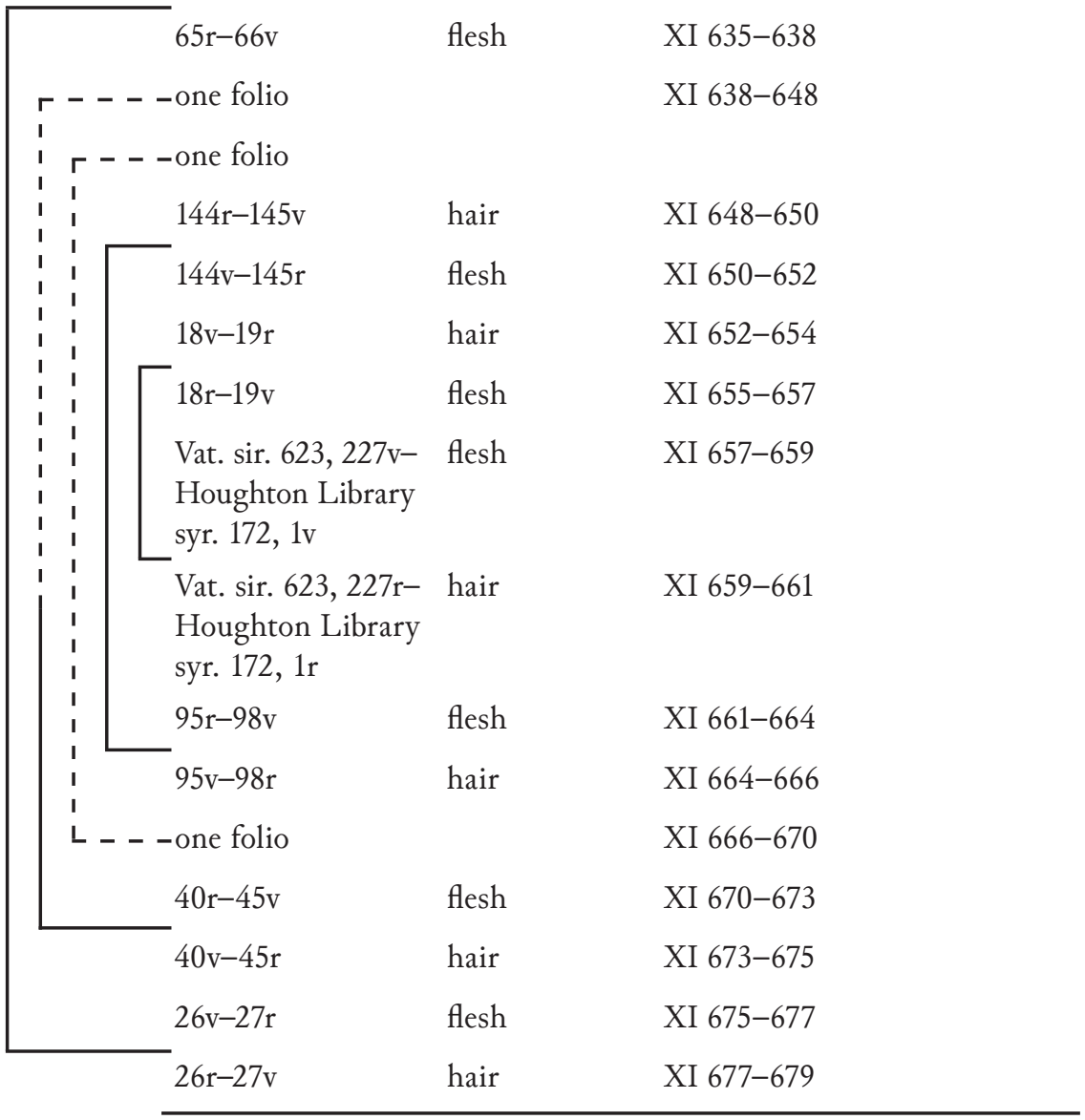


TABLE 1. The "skeleton" (cont.).

\begin{tabular}{llll}
\hline $\begin{array}{l}\text { Syriac Galen } \\
\text { Palimpsest }\end{array}$ & $\begin{array}{l}\text { Parchment } \\
\text { characteristics, } \\
\text { quires }\end{array}$ & Kübn's edition & $\begin{array}{l}\text { Book of } \\
\text { Galen's “On } \\
\text { simple drugs” }\end{array}$ \\
\hline $64 \mathrm{v}-67 \mathrm{r}$ & hair (quire & XI 679-681 &
\end{tabular}

IX), quire

signature teth

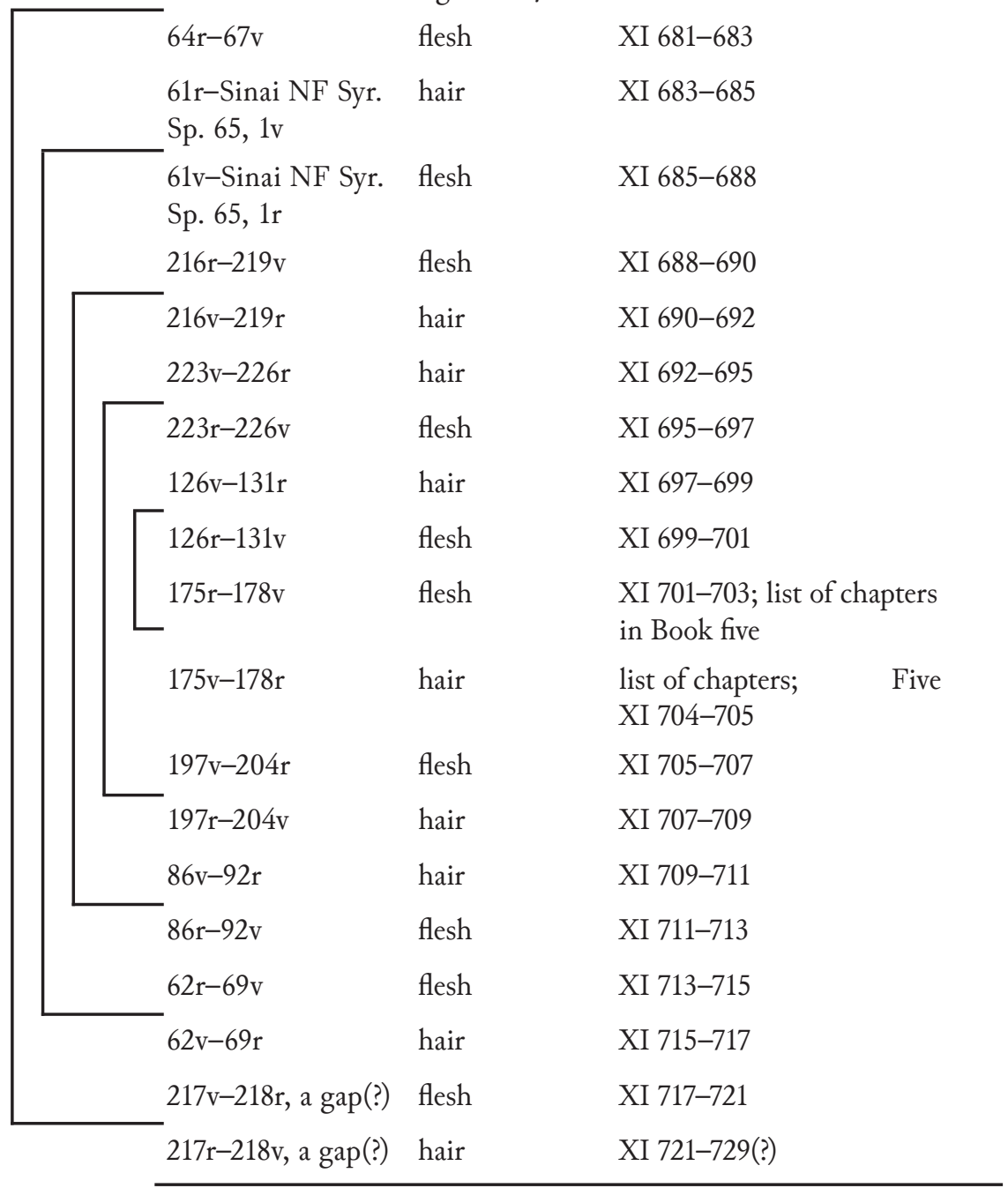


TABLE 1. The "skeleton" (cont.).

\begin{tabular}{|c|c|c|c|}
\hline $\begin{array}{l}\text { Syriac Galen } \\
\text { Palimpsest }\end{array}$ & $\begin{array}{l}\text { Parchment } \\
\text { characteristics, } \\
\text { quires }\end{array}$ & Kübn's edition & $\begin{array}{l}\text { Book of } \\
\text { Galen's "On } \\
\text { simple drugs" }\end{array}$ \\
\hline $94 r-99 v$ & hair (quire $\mathrm{X}$ ) & XI 729(?)-730 & \\
\hline $94 \mathrm{v}-99 \mathrm{r}$ & flesh & XI 730-732 & \\
\hline $103 v-106 r$ & hair & XI 732-734 & \\
\hline $103 r-106 v$ & flesh & XI 734-736 & \\
\hline $199 \mathrm{v}-202 \mathrm{r}$ & hair & XI 736-738 & \\
\hline $199 \mathrm{r}-202 \mathrm{v}$ & flesh & XI 738-740 & \\
\hline $25 r-28 v$ & hair & XI 740-742 & \\
\hline $25 v-28 r$ & flesh & XI 742-745 & \\
\hline $80 v-83 r$ & hair & XI 745-747 & \\
\hline $80 r-83 v$ & flesh & XI 747-749 & \\
\hline $110 v-115 r(?)$ & flesh & XI 749-751 & \\
\hline $110 \mathrm{r}-115 \mathrm{v}$ (?) & hair & XI 751-753 & \\
\hline $205 r-213 v$ & flesh & XI 753-756 & \\
\hline $205 \mathrm{v}-213 \mathrm{r}$ & hair & XI 756-758 & \\
\hline $7 \mathrm{r}-14 \mathrm{v}$ & flesh & XI 758-760 & \\
\hline $7 v-14 r$ & hair & XI 760-762 & \\
\hline $190 \mathrm{v}-195 \mathrm{r}$ & flesh & XI 762-764 & \\
\hline $190 \mathrm{r}-195 \mathrm{v}$ & hair & XI 764-766 & \\
\hline $93 \mathrm{r}-100 \mathrm{v}(?)$ & flesh & XI 766-768 & \\
\hline $93 \mathrm{v}-100 \mathrm{r}(?)$ & hair & XI 768-771 & \\
\hline
\end{tabular}


TABLE 1. The "skeleton" (cont.).

\begin{tabular}{|c|c|c|c|c|}
\hline & $\begin{array}{l}\text { Syriac Galen } \\
\text { Palimpsest }\end{array}$ & $\begin{array}{l}\text { Parchment } \\
\text { characteristics, } \\
\text { quires }\end{array}$ & Kübn's edition & $\begin{array}{l}\text { Book of } \\
\text { Galen's “On } \\
\text { simple drugs" }\end{array}$ \\
\hline & $181 \mathrm{v}-188 \mathrm{r}$ & hair (quire XI) & XI 771-774 & \\
\hline & $181 \mathrm{r}-188 \mathrm{v}$ & flesh & XI 774-776 & \\
\hline & $15 \mathrm{r}-22 \mathrm{v}$ & hair & XI 776-778(?) & \\
\hline & $15 \mathrm{v}-22 \mathrm{r}$ & flesh & XI 778(?)-781 & \\
\hline & -one folio & & XI 781-786 & \\
\hline 1 & $48 r-53 v$ & hair & XI 786-788 & \\
\hline $\begin{array}{l}1 \\
1 \\
1 \\
1 \\
1\end{array}$ & $48 v-53 r$ & flesh & $\begin{array}{l}\text { Sergius's } \\
\text { introduction } \\
\text { to Book six }\end{array}$ & Six \\
\hline $\begin{array}{l}1 \\
1 \\
1 \\
1 \\
1\end{array}$ & $34 v-35 r$ & hair & $\begin{array}{l}\text { Sergius's } \\
\text { introduction, } \\
\text { list of plants }\end{array}$ & \\
\hline 1 & $34 r-35 v$ & flesh & list of plants & \\
\hline & $16 \mathrm{r}-21 \mathrm{v}$ & flesh & list of plants & \\
\hline & $16 \mathrm{v}-21 \mathrm{r}$ & hair & $\begin{array}{l}\text { list of plants; } \\
\text { XI 789-790 }\end{array}$ & \\
\hline & $157 \mathrm{r}-164 \mathrm{v}$ & flesh & XI 790-792 & \\
\hline & $157 \mathrm{v}-164 \mathrm{r}$ & hair & XI 792-794 & \\
\hline & $17 r-20 v$ & flesh & XI 794-796 & \\
\hline & $17 \mathrm{v}-20 \mathrm{r}$ & hair & XI 796-798 & \\
\hline & $1 \mathrm{v}-4 \mathrm{r}$ & flesh & XI 798-800 & \\
\hline & $1 \mathrm{r}-4 \mathrm{v}$ & hair & XI 800-802 & \\
\hline & $\begin{array}{l}\text { Vat. sir. 647, } \\
38 v-6 r\end{array}$ & flesh & XI 802-804 & \\
\hline & $\begin{array}{l}\text { Vat. sir. 647, } \\
38 \mathrm{r}-6 \mathrm{v}\end{array}$ & hair & XI 804-805 & \\
\hline & ten folios & $\begin{array}{l}\text { (quire XII } \\
\text { missing) }\end{array}$ & XI 805-854 & \\
\hline
\end{tabular}


TABLE 1. The "skeleton" (cont.).

\begin{tabular}{|c|c|c|c|}
\hline $\begin{array}{l}\text { Syriac Galen } \\
\text { Palimpsest }\end{array}$ & $\begin{array}{l}\text { Parchment } \\
\text { characteristics, } \\
\text { quires }\end{array}$ & Kübn's edition & $\begin{array}{l}\text { Book of } \\
\text { Galen's “On } \\
\text { simple drugs" }\end{array}$ \\
\hline $109 \mathrm{v}-116 \mathrm{r}$ & $\begin{array}{l}\text { hair (quire } \\
\text { XIII) }\end{array}$ & XI 854-857 & \\
\hline $109 \mathrm{r}-116 \mathrm{v}$ & flesh & XI 857-859 & \\
\hline $111 \mathrm{v}-114 \mathrm{r}$ & hair & XI 859-862 & \\
\hline $111 \mathrm{r}-114 \mathrm{v}$ & flesh & XI 862-865 & \\
\hline -one folio & & XI 865-870 & \\
\hline $176 \mathrm{r}-177 \mathrm{v}$ & hair & XI 870-872 & \\
\hline $176 \mathrm{v}-177 \mathrm{r}$ & flesh & XI 872-875 & \\
\hline $55 \mathrm{r}-60 \mathrm{v}$ & hair & XI 875-877 & \\
\hline $55 \mathrm{v}-60 \mathrm{r}$ & flesh & XI 878-881 & \\
\hline $104 \mathrm{v}-105 \mathrm{r}$ & flesh & XI 882-884 & \\
\hline $104 r-105 v$ & hair & XI 884-886 & \\
\hline $41 \mathrm{r}-44 \mathrm{v}(?)$ & flesh & XI 887-889 & \\
\hline $41 v-44 r(?)$ & hair & XI 889-892 & \\
\hline $118 v-123 r$ & flesh & $\begin{array}{l}\text { Sergius's } \\
\text { introduction } \\
\text { to Book seven }\end{array}$ & Seven \\
\hline $118 \mathrm{r}-123 \mathrm{v}$ & hair & list of plants & \\
\hline $198 r-203 v$ & flesh & list of plants & \\
\hline $198 v-203 r$ & hair & XII 1-4 & \\
\hline $70 \mathrm{r}-77 \mathrm{v}$ & flesh & XII 4-7 & \\
\hline $70 v-77 r$ & hair & XII 7-9 & \\
\hline
\end{tabular}


TABLE 1. The "skeleton" (cont.).

\begin{tabular}{|c|c|c|c|}
\hline $\begin{array}{l}\text { Syriac Galen } \\
\text { Palimpsest }\end{array}$ & $\begin{array}{l}\text { Parchment } \\
\text { characteristics, } \\
\text { quires }\end{array}$ & Kübn's edition & $\begin{array}{l}\text { Book of } \\
\text { Galen's “On } \\
\text { simple drugs” }\end{array}$ \\
\hline $112 \mathrm{r}-113 \mathrm{v}$ & $\begin{array}{l}\text { hair (quire } \\
\text { XIV) }\end{array}$ & XII 9-12 & \\
\hline $112 \mathrm{v}-113 \mathrm{r}$ & flesh & XII 12-14 & \\
\hline $159 \mathrm{v}-162 \mathrm{r}$ & hair & XII 14-17 & \\
\hline $159 \mathrm{r}-162 \mathrm{v}$ & flesh & XII 17-19 & \\
\hline $200 \mathrm{v}-201 \mathrm{r}$ & hair & XII 19-21 & \\
\hline $200 \mathrm{r}-201 \mathrm{v}$ & flesh & XII 21-24 & \\
\hline $\begin{array}{l}\text { Vat. sir. 647, } \\
39 v-5 r\end{array}$ & hair & XII 24-27 & \\
\hline $\begin{array}{l}\text { Vat. sir. 647, } \\
\text { 39r-5v }\end{array}$ & flesh & XII 27-29 & \\
\hline $\begin{array}{l}\text { L -one folio } \\
\text { Lolio }\end{array}$ & & XII 29-42 & \\
\hline $102 \mathrm{r}-107 \mathrm{v}$ & flesh & XII 42-44 & \\
\hline $102 \mathrm{v}-107 \mathrm{r}$ & hair & XII 44-46 & \\
\hline $165 r-172 v$ & flesh & XII 46-49 & \\
\hline $165 \mathrm{v}-172 \mathrm{r}$ & hair & XII 49-51 & \\
\hline $208 \mathrm{r}-209 \mathrm{v}$ & flesh & XII 51-54 & \\
\hline $208 \mathrm{v}-209 \mathrm{r}$ & hair & XII 54-56 & \\
\hline $96 \mathrm{v}-97 \mathrm{r}$ & flesh & XII 56-60 & \\
\hline $96 \mathrm{r}-97 \mathrm{v}$ & hair & XII 60-62 & \\
\hline
\end{tabular}


TABLE 1. The "skeleton" (cont.).

\begin{tabular}{|c|c|c|c|c|}
\hline & $\begin{array}{l}\text { Syriac Galen } \\
\text { Palimpsest }\end{array}$ & $\begin{array}{l}\text { Parchment } \\
\text { characteristics, } \\
\text { quires }\end{array}$ & Kübn's edition & $\begin{array}{l}\text { Book of } \\
\text { Galen's "On } \\
\text { simple drugs" }\end{array}$ \\
\hline \multicolumn{2}{|c|}{ 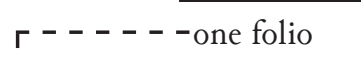 } & (quire XV) & XII $62-67$ & \\
\hline & $47 \mathrm{r}-54 \mathrm{v}$ & hair & XII 67-70 & \\
\hline & $47 \mathrm{v}-54 \mathrm{r}$ & flesh & XII 70-72 & \\
\hline & $72 v-75 r$ & hair & XII 72-75 & \\
\hline & $72 \mathrm{r}-75 \mathrm{v}$ & flesh & XII 75-77 & \\
\hline & $101 \mathrm{r}-108 \mathrm{v}$ & hair & XII 77-80 & \\
\hline & $101 v-108 \mathrm{r}$ & flesh & XII $80-82$ & \\
\hline & {$\left[\begin{array}{l}r^{-} \text {one folio } \\
\mathrm{L} \text {-one folio }\end{array}\right.$} & & $\begin{array}{l}\text { Sergius's } \\
\text { introduction to } \\
\text { Book eight; list } \\
\text { of chapters }\end{array}$ & Eight \\
\hline & $192 \mathrm{v}-193 \mathrm{r}$ & flesh & XII 84-86(?) & \\
\hline & $192 \mathrm{r}-193 \mathrm{v}$ & hair & XII 86(?)-89 & \\
\hline & $57 \mathrm{v}-58 \mathrm{r}$ & flesh & XII 89-92 & \\
\hline & $57 \mathrm{r}-58 \mathrm{v}$ & hair & XII 92-95 & \\
\hline & $158 \mathrm{v}-163 \mathrm{r}$ & flesh & XII 95-98 & \\
\hline & $158 \mathrm{r}-163 \mathrm{v}$ & hair & XII 98-100 & \\
\hline & $173 \mathrm{v}-180 \mathrm{r}$ & flesh & XII 100-103 & \\
\hline & $173 \mathrm{r}-180 \mathrm{v}$ & hair & XII 103-106 & \\
\hline
\end{tabular}

Codicology and Paleography of the Original Medical Manuscript

The SGP is remarkable in that every folio contains undertext that belongs to a single original manuscript containing only one literary work. This permits the following analysis of the structure of the original medical manuscript. 
144 | Journal For Manuscript Studies

TABLE 1. The "skeleton" (cont.).

\begin{tabular}{lll}
\hline Syriac Galen & $\begin{array}{l}\text { Parchment } \\
\text { characteristics, }\end{array}$ & Kübn's edition \\
Palimpsest & quires & $\begin{array}{l}\text { Book of } \\
\text { Galen's “On } \\
\text { simple drugs” }\end{array}$ \\
\hline
\end{tabular}

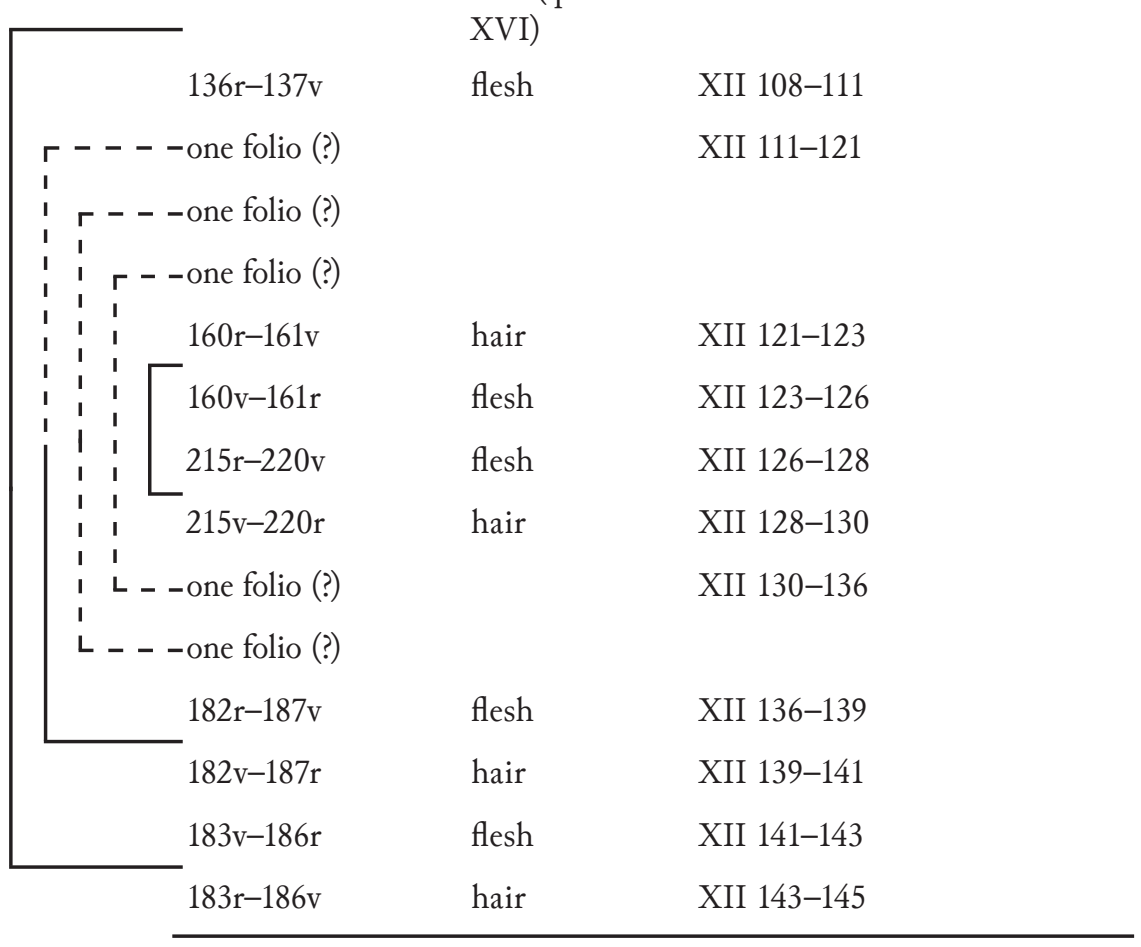

\section{QUIRES}

We have been able to reconstruct the structure of the original manuscript, as shown in Table $1 .^{65}$ We identified the hair and flesh sides of the folios and analyzed their sequence by scrutinizing the pre-conservation color

65 We owe the first identified sets of bifolia to Robert Hawley; see Hawley, "More Identifications," 237-72. 
TABLE 1. The "skeleton" (cont.).

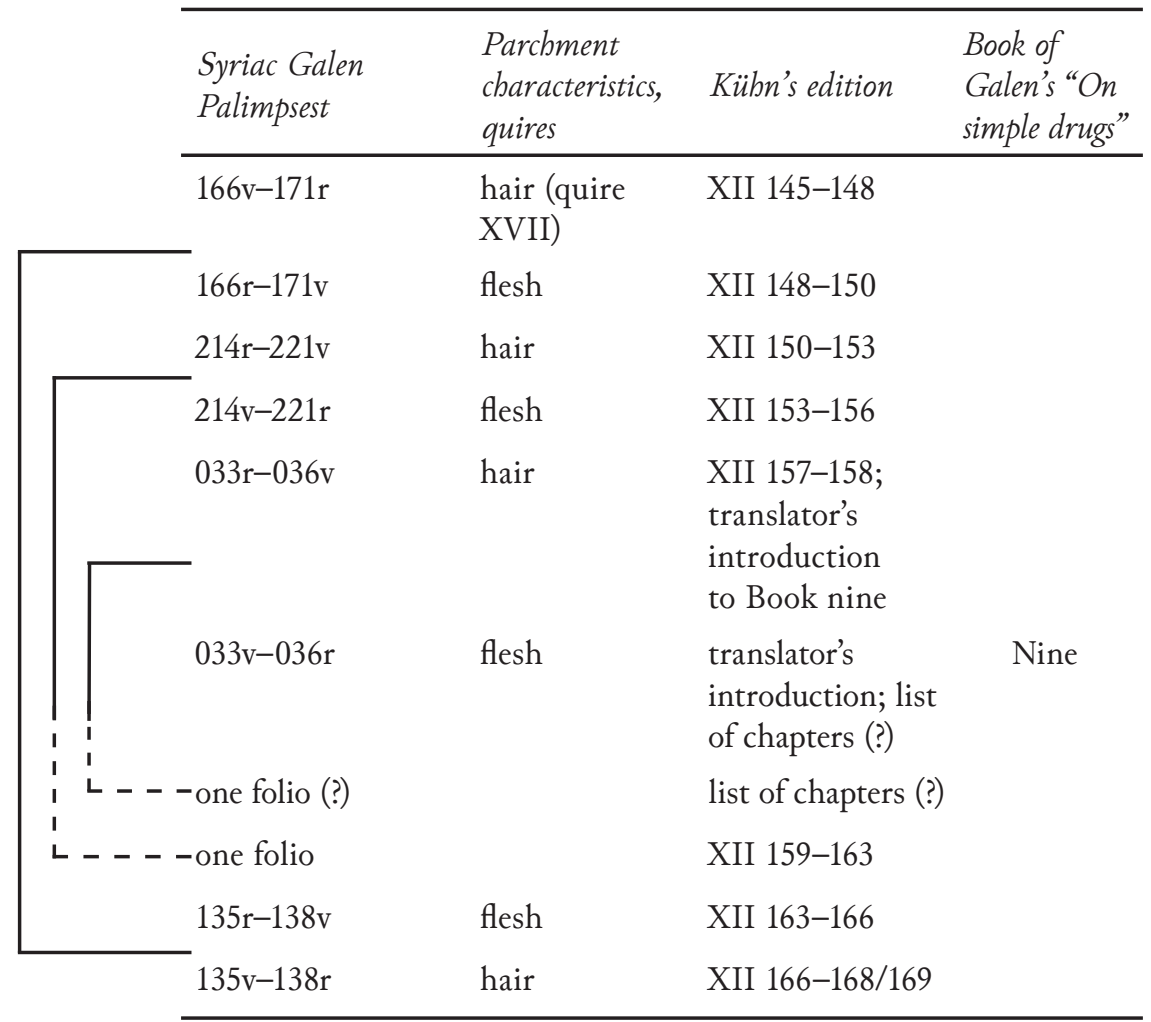

photographs of the bound palimpsest. ${ }^{66}$ The quires are quinions-that is, quires of five bifolia (ten folios) - folded flesh-side inwards so that each quire begins and ends with a hair side. The folding pattern for each quinion is consistent throughout the manuscript: hair-flesh-hair-flesh-hairflesh-hair-flesh-hair-flesh-flesh-hair-flesh-hair-flesh-hair-flesh-hair-fleshbair. There is, however, one exception-namely, quire 9, which follows a

66 “The Digital Walters," http://www.thedigitalwalters.org/Data/OtherCollections/html/ PC4/, accessed 16 June 2017. We are grateful to Renée Wolcott for bringing this resource to our attention. 
TABLE 1. The "skeleton" (cont.).

\begin{tabular}{llll}
\hline $\begin{array}{l}\text { Syriac Galen } \\
\text { Palimpsest }\end{array}$ & $\begin{array}{l}\text { Parcbment } \\
\text { characteristics, } \\
\text { quires }\end{array}$ & Kühn's edition & $\begin{array}{l}\text { Book of } \\
\text { Galen's “On } \\
\text { simple drugs” }\end{array}$ \\
\hline $73 \mathrm{v}-74 \mathrm{r}$ & hair (quire & XII 168/169-171 &
\end{tabular}

$73 \mathrm{r}-74 \mathrm{v}$
$\mathrm{r}_{-}--$- one folio

XVIII)

$\mathrm{r}$
$\mathrm{i}$
$\mathrm{i}$
$\mathrm{i}$
$\mathrm{i}$
$\mathrm{r}$
$\mathrm{r}$
$\mathrm{r}$
$\mathrm{r}$

flesh

XII 171-173

XII 173-178

hair XII 178-180

flesh XII 180-182

hair XII 182-185

flesh

XII 185-188

XII 188-192

flesh

Beginning not

$184 \mathrm{v}-185 \mathrm{r}$

in Kühn, XII

192-193

hair

XII 193-195

flesh

XII 195-198

hair

XII 198-201

flesh

XII 201-203

hair

XII 203-206

BnF syr. 382, flesh

XII 206-209 $10 \mathrm{r}-88 \mathrm{r}$

BnF syr. 382, hair

XII 209-212

$10 \mathrm{v}-88 \mathrm{v}$

$206 \mathrm{r}-212 \mathrm{v}$

flesh

XII 212-214

$206 \mathrm{v}-212 \mathrm{r}$

hair

XII 214-217

approx. forty

folios

(quires XIX- XII 217-244

$\mathrm{XXII}[?]$

missing)

XII 245-309

Ten (not

represented)

XII 310-377 Eleven (not represented) 
different pattern: bair-flesh-hair-flesh-flesh-hair-hair-flesh-hair-flesh-fleshhair-flesh-hair-hair-flesh-flesh-hair-flesh-bair. ${ }^{67}$

If the original manuscript only contained Galen's On Simple Drugs, which appears likely, then it consisted of twenty-two quinions, of which fourteen have survived. Quire signatures are visible on the bottom righthand corner of two pages: waw marks the sixth quire on folios $120 \mathrm{r}-121 \mathrm{v}$, and tẹe the ninth on folios $64 \mathrm{v}-67 \mathrm{r}$. The first and last preserved quires of the original manuscript are the fourth and eighteenth, respectively. It thus appears that we are missing three quires at the beginning, one in the middle, and at least four at the end of the codex. Furthermore, approximately twentyfour individual folios are missing from the middle.

Quire 17 appears to be a ternion rather than a quinion, thus breaking the regular structure. There are likely to be two missing folios at the beginning of Book 9, containing the translator's preface, a table of contents, and the first chapter of Galen's text (up to Kühn XII.163). The number of folios needed to complete the quinion does not accord with the existing lacuna. We hope, however, that some of the hitherto unidentified folios might shed additional light on this.

\section{TeXt Layout}

There are no visible traces of ruling or pricking that belong to the original manuscript. Despite this, the layout of the text is reasonably consistent. Each page has two columns that are justified on the right-hand side. The left-hand side is also justified, although less strictly, often by means of an extra space before the last word. The top and bottom lines of each column are also justified, although the lines in the middle, particularly in column $\mathrm{B}$, can slant upwards as much as six degrees from the baseline (for example,

67 See Afif et al., “The Syriac Galen Palimpsest," 5-16. Quinions are common in the Syriac tradition in general and in manuscripts of the ninth and tenth centuries in particular; see Brock, "Syriac Manuscripts of the 9th-10th Centuries," 157-64; P. G. Borbone, F. BriquelChatonnet, and E. Balicka-Witakowska, "Syriac Codicology," in Comparative Oriental Manuscript Studies, ed. A. Bausi (Hamburg: COMSt, 2015), 252-66. 
fols. 111v-114r). This leads us to the conclusion that the parchment was probably ruled with a lead pencil, but the ruling was subsequently erased by the scribe. The side margins very much helped with the identification of the undertext. A folio's verso is characterized by a broad (outer) margin on the right-hand side with a narrow (inner) margin on the left-hand side, while the recto has a broad margin on the left with a narrow margin on the right.

To date, we have not identified any running titles or catchwords. In the margins, there are chapter numbers between two short horizontal lines. Occasionally, other signs are used, probably to mark quotations. A number of folios (for example, fols. $70 \mathrm{v}-77 \mathrm{r}$ ) display a small cross, comprising four dots, located in the right-hand margin beside the start of column A (see fig. 1). The crosses are present where the text is not the beginning of a book or chapter; therefore, their meaning and function remains unclear.

With the ImageJ tool's ruler, we measured the length and width of the columns, gutter, and margins. Table 2 shows approximate results for quire 13 , which is representative, as it contains both the main text of the treatise and a table of contents, in this case the list of plants at the beginning of Book 7 (fols. 118r-123v). Some folios contain gaps of several lines between sections, a usual practice in the undertext, although the number of lines without text varies. The results can be summed up as follows:

- Column: 164-180 × 47-56 millimeters, with 35-44 lines

- Outer margin: 40-46 millimeters

- Gutter (inner margin): 15-22 millimeters

- Intercolumnar: 11-16 millimeters

- Header: 29-35 millimeters

- Footer: 46-53 millimeters

The maximum dimensions of the writing area within the examined quire are approximately $180 \times 120$ millimeters. The variation in the width of the margins is probably due to the trimming when the manuscript was recycled. Column width and length may vary on pages that include tables of contents (lists of chapters or names of plants). The minimum number of 


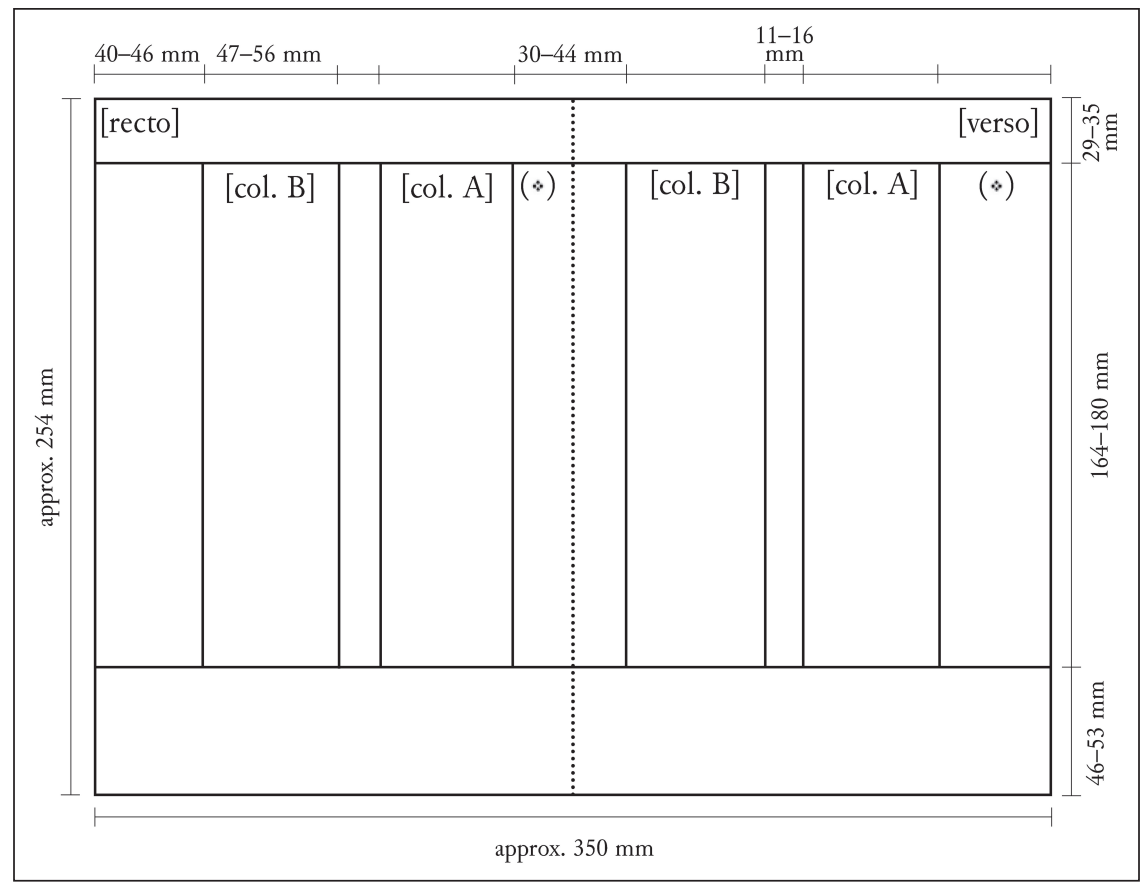

FIGURE 1. Outline detailing the approximate measurements of a bifolium in the original medical manuscript.

lines per column is thirty-three, and free space within the line may be filled with ornamental dots (for example, fols. $34 \mathrm{r}-35 \mathrm{v}, 16 \mathrm{r}-21 \mathrm{v}$ ). ${ }^{68}$

\section{Paleography and Provisional Date}

To describe the script, we employ a paleographical method devised by Ayda Kaplan at the Université Catholique de Louvain, focusing on Syriac manuscripts dated to the ninth century, the provisional date for the undertext of the SGP. ${ }^{69}$ The script displays both cursive and monumental (estrangelo)

68 See Afif et al., "The Syriac Galen Palimpsest," 9.

69 A. Kaplan, Paléographie syriaque: développement d'une méthode d'expertise sur base des manuscrits syriaques de la British Library (Ve-Xe siècles), Ph.D. thesis (Louvain-la-Neuve: Université 
Manuscript Studies, Vol. 3 [2019], Iss. 1, Art. 6

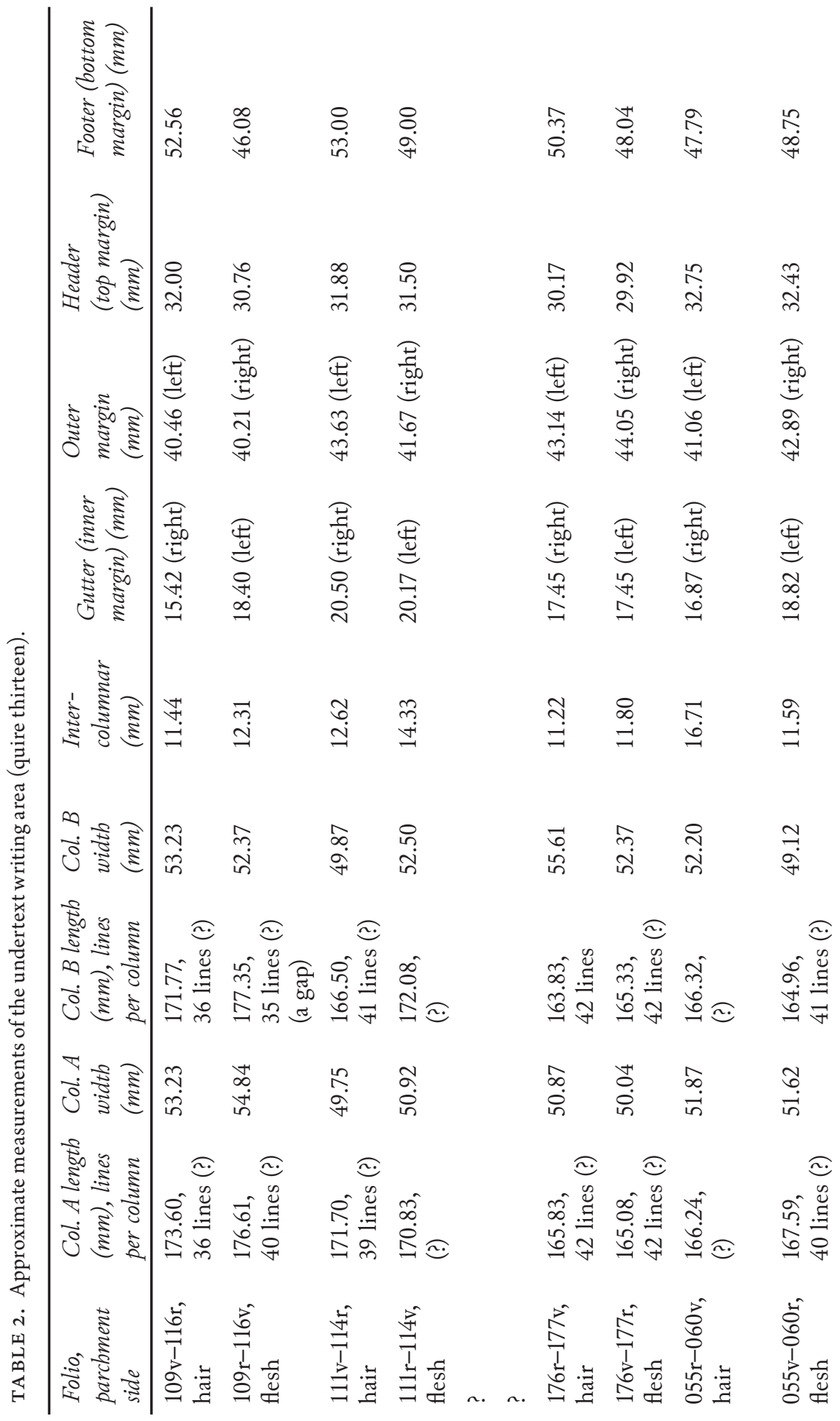


Afif et al.: The Syriac Galen Palimpsest: A Tale of Two Texts

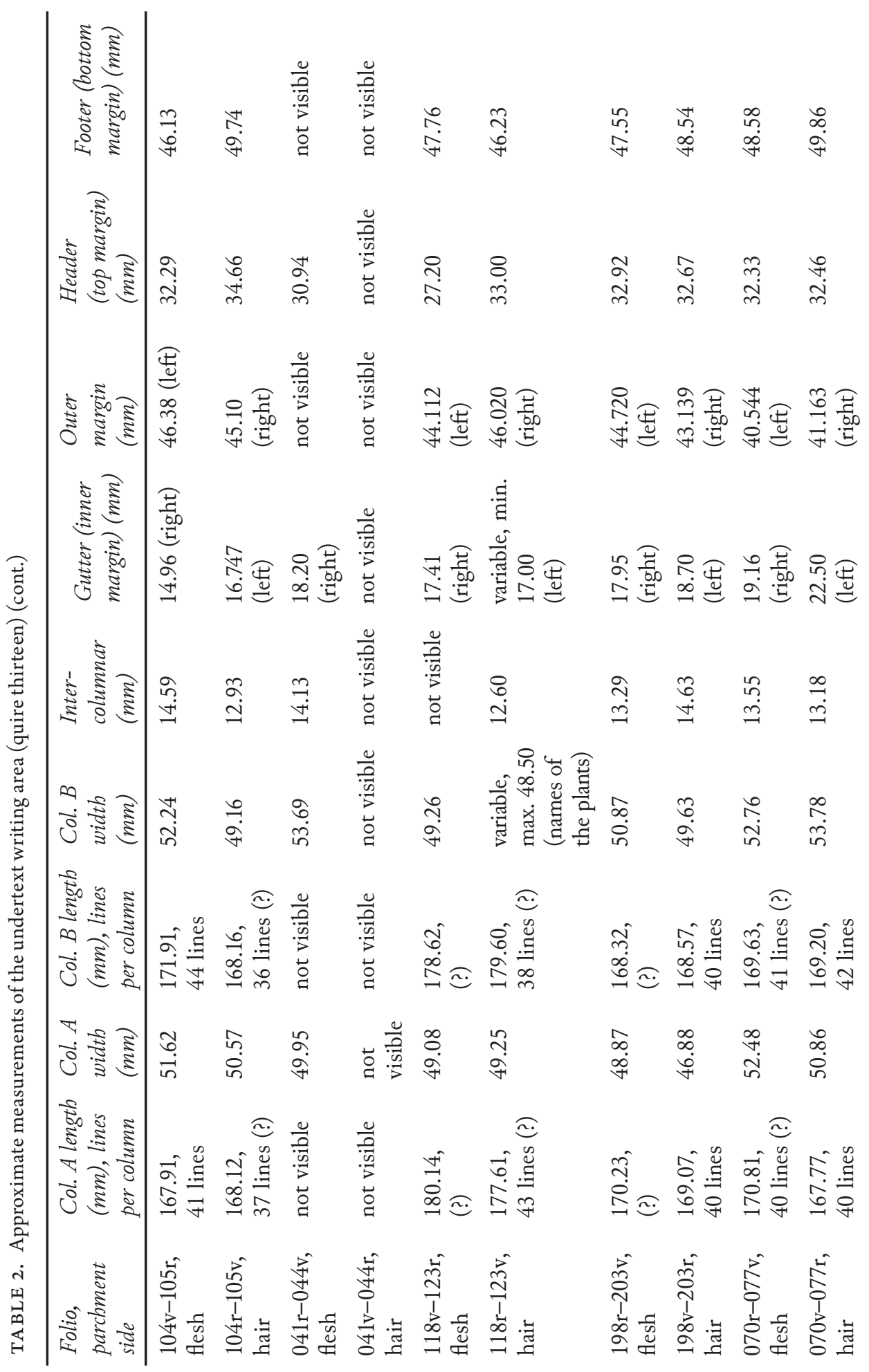


elements. The letters bēt, gāmal, tẹet, kāp (both regular and final), mìm (final), nūn (final), $p \bar{e}, s \underline{a} \bar{d} \bar{e} \bar{e}, q \bar{o} \bar{p}$, and š̀n appear only in monumental form, while āla $\bar{p}$ and taw may take either monumental or cursive form. All the other letters appear in cursive form, which dominates the general appearance.

In paleographical terms, the SGP resembles another remarkable Sinaitic manuscript, whose history is somewhat similar to that of the SGP. Known as the Sahdona manuscript, it contains the Book of Perfection, a fine example of Syriac monastic literature, as well as letters and aphorisms, and was written by Sahdona (also known as Martyrius), an East Syrian, albeit proChalcedonian, author of the seventh century. As the colophon shows, the manuscript was copied in Edessa in 837 CE (AG 1148) by the monk Abbā

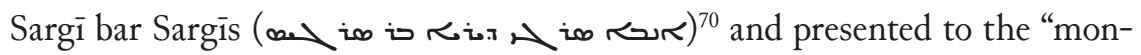
astery of Moses" on Mount Sinai. ${ }^{71}$ While the main part of this manuscript is now kept in the National University Library (BNU) in Strasbourg (MS.4.116), fragments are scattered among a number of other libraries in Europe and the Middle East. ${ }^{72}$ Although the main text is written in estran-

catholique de Louvain, 2008); A. Kaplan, "Expertise paléographique du ms. Syr Bagdad 210 en vue de sa datation," BABELAO (Electronic Journal for Ancient and Oriental Studies) 2 (2013): 105-21; A. Kaplan, "La paléographie syriaque: proposition d'une méthode d'expertise," in Manuscripta Syriaca: des sources de première main, ed. F. Briquel-Chatonnet and M. Debié, Cahiers d'études syriaques 4 (Paris: Geuthner, [2015]), 307-20.

70 The full text of the colophon (St. Petersburg, Russian National Library, Syr. New Series 13, fol. 2r) was published with a German translation in N. Pigulewsky, "Das Ende der Straasburger Sahdona-Handschrift: herausgegeben und übersetzt,” Oriens Christianus, Ser. 3, 1 (1927): 293-309.

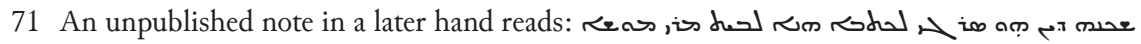

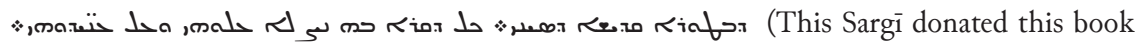
to the monastery of Mar Moses, which is on the Holy Mount Sinai. Let everyone who reads it pray for him those departed with him) (fol. 2r).

72 E.g., Milan, Biblioteca Ambrosiana, MS A 296 inf, fols. 131-42 (see A. de Halleux, "Un nouveau fragment de manuscript sinaitique de Martyrius-Sahdona," Le Muséon 73 (1960): 33-38; Birmingham, University Library, Mingana Syr. 650 (see S. Brock, "A further fragment of the Sinai Sahdona Manuscript," Le Muséon 81 [1968]: 139-54); Sinai, St. Catherine's Monastery, Syriac New Finds M45N (see S. Brock, "New Fragments of Sahdona's Book of Perfection at St. Catherine's Monastery, Mount Sinai," Orientalia Christiana Periodica 75 
gelo, the script of the colophon is particularly close to the SGP's undertext, with a comparable mixture of monumental and cursive writing. Based on this observation, we can now tentatively date it to either the first half or the middle of the ninth century, which falls approximately within the time when Hunayn ibn Ishāq was active as a translator of works by Galen into Syriac and Arabic. The original manuscript must have been copied in Edessa or another, not too distant, place in northern Mesopotamia.

\section{Conclusion}

This, then, is the first comprehensive description of the SGP's two faces. We would like to acknowledge here that we could only tell this tale of two manuscripts thanks to its anonymous owner. He took seriously the responsibilities that accompany such an acquisition: not only did he support its conservation, processing, and other more technical aspects of its care, but by making digital images freely available, he created the conditions for the scholarly community to engage with it. In many respects, this was also demonstrated in the treatment of the previous comparable project, the Archimedes Palimpsest, yet the crucial difference here, of course, is that both Galen and Syriac are considerably less known and fashionable in the popular imagination than ancient Greek and Archimedes. In these respects, especially, the owner should be congratulated. Further, his commitment to making the data freely available contributes greatly to the democratization of research and knowledge.

Based on this data set, the study of the SGP's history was very much a collective effort, and together, we have made major strides in the study of the SGP as a historical object with its double history, as this article demonstrates. To be sure, one can always push the boundaries of knowledge further, but we are confident that the general picture that we paint here

[2009]: 175-78); and the St. Petersburg, Russian National Library, Syr. New Series 13 (see Pigulewsky, “Das Ende,” 293-309). 
154 | Journal for Manuscript Studies

will not change. The same cannot be said for the content of the undertext, much of which still remains to be deciphered, even if most leaves have been identified. It is in this area that we shall now focus all our energy during our Manchester project, which we describe in the next article in this volume. 